OPEN ACCESS

Edited by:

Ralf J. Ludwig,

Universität zu Lübeck, Germany

Reviewed by:

Mohey Eldin El Shikh,

Queen Mary University of London,

United Kingdom

Reinhild Klein,

Universität Tübingen, Germany

*Correspondence: Martin K. Church

mkc@soton.ac.uk

Specialty section: This article was submitted to Immunological Tolerance and

Regulation,

a section of the journal

Frontiers in Immunology

Received: 02 February 2018

Accepted: 20 March 2018

Published: 09 April 2018

Citation:

Maurer M, Altrichter S, Schmetzer O, Scheffel J, Church MK and Metz M (2018) Immunoglobulin E-Mediated

Autoimmunity.

Front. Immunol. 9:689. doi: 10.3389/fimmu.2018.00689

\section{Immunoglobulin E-Mediated Autoimmunity}

\author{
Marcus Maurer, Sabine Altrichter, Oliver Schmetzer, Jörg Scheffel, Martin K. Church and \\ Martin Metz
}

Department of Dermatology and Allergy, Charité - Universitätsmedizin Berlin, Berlin, Germany

The study of autoimmunity mediated by immunoglobulin E ( $\mathrm{lgE}$ ) autoantibodies, which may be termed autoallergy, is in its infancy. It is now recognized that systemic lupus erythematosus, bullous pemphigoid (BP), and chronic urticaria, both spontaneous and inducible, are most likely to be mediated, at least in part, by lgE autoantibodies. The situation in other conditions, such as autoimmune uveitis, rheumatoid arthritis, hyperthyroid Graves' disease, autoimmune pancreatitis, and even asthma, is far less clear but evidence for autoallergy is accumulating. To be certain of an autoallergic mechanism, it is necessary to identify both IgE autoantibodies and their targets as has been done with the transmembrane protein BP180 and the intracellular protein BP230 in BP and IL-24 in chronic spontaneous urticaria. Also, IgE-targeted therapies, such as anti-lgE, must have been shown to be of benefit to patients as has been done with both of these conditions. This comprehensive review of the literature on lgE-mediated autoallergy focuses on three related questions. What do we know about the prevalence of lgE autoantibodies and their targets in different diseases? What do we know about the relevance of IgE autoantibodies in different diseases? What do we know about the cellular and molecular effects of IgE autoantibodies? In addition to providing answers to these questions, based on a broad review of the literature, we outline the current gaps of knowledge in our understanding of IgE autoantibodies and describe approaches to address them.

Keywords: immunoglobulin E-mediated autoimmunity, autoallergy, urticaria, bullous pemphigoid, immunoglobulin E-mechanisms

\section{INTRODUCTION}

Friend or Foe? This is the major question that the immune system must address in every individual from the time of conception, through the development of the fetus and the child, right into adulthood. But sometimes it gets this wrong and raises an inappropriate immunological response against self. Although there are several types of autoimmunity this review will address solely immunoglobulin $\mathrm{E}$ (IgE)-mediated autoimmunity. Because its mechanisms have much in common with classical allergy involving exogenous allergens, such as grass pollen or house dust mites, IgE-mediated autoimmunity is generally termed "autoallergy" and the target molecules of the response are called "autoallergens."

Although the presence of an allergic antibody has been postulated since the innovative serum transfer experiment of Prausnitz and Kustner in 1921 (1), it was not until 1967 that this antibody was characterized as $\operatorname{IgE}(2-4)$. IgE, which is the least abundant immunoglobulin isotype and found only in mammals, signals through 2 types of Fce receptor, the high-affinity receptor, FceRI, which is found primarily on mast cells and basophils, and the low-affinity receptor, FceRII or CD23, a C-type 
lectin, which is found on mature B cells, activated macrophages, eosinophils, follicular dendritic cells, and platelets. The primary role of IgE is held to be host defense, particularly initiating the expulsion of parasitic worms (helminths) and environmental substances, such as toxins, venoms, irritants, and xenobiotics.

Although IgE has a well-documented role in classical allergy to exogenous allergens, this review will address only IgE-mediated autoimmunity. It will focus on three related questions: what do we know about the prevalence of $\operatorname{IgE}$ autoantibodies and their targets in different diseases? What do we know about the relevance of IgE autoantibodies in different diseases? What do we know about the cellular and molecular effects of IgE autoantibodies? In addition to providing answers to these three questions, based on a comprehensive review of the literature, we outline the current gaps of knowledge in our understanding of IgE autoantibodies and describe approaches to address them.

\section{WHAT DO WE KNOW ABOUT THE PREVALENCE OF IgE AUTOANTIBODIES AND THEIR TARGETS IN DIFFERENT CONDITIONS?}

Within a decade of its discovery, reports began to incriminate $\operatorname{IgE}$ as a possible contributor to the pathogenesis of several chronic inflammatory disorders, such as rheumatoid arthritis (RA) (5-7), bullous pemphigoid (BP) $(8,9)$, atopic dermatitis (AD) (10), and systemic lupus erythematosus (SLE) $(11,12)$. More recently, IgE-mediated autoallergy has been suggested for other disorders including chronic spontaneous urticaria (CSU) $(13,14)$ and chronic inducible urticaria (CindU) (15). The conditions in which IgE autoantibodies have been detected, which are summarized in Table 1, will now be considered in more detail.

\section{Atopic Dermatitis}

Decades before the discovery of IgE, it was reported that human dander extract can elicit immediate-type skin reactions in patients with severe atopy and that this skin sensitivity could be passively transferred with serum (30-35). Many years later, the analysis of the presence of $\operatorname{IgE}$ autoantibodies in sera from patients with various manifestations of atopy and other autoimmune disorders indicated that $\operatorname{IgE}$ reactivity against a variety of autoantigens occurred most frequently in $\mathrm{AD}$ patients. $\mathrm{IgE}$ autoreactitvy has first been found and described in AD (36), where IgE autoantibodies are very frequent (23-91\%) (19) and especially present in severely affected patients (37-39). IgE autoantibodies had been identified directed against Keratinocytes (40) and a broad variety of autoantigens (41), including, e.g., human protein manganese superoxide dismutase (38), thioredoxin (42), DFS70/LEDGF (43), and Hom s 1-5 $(44,45)$.

Interestingly, this phenomenon has already been seen in very young infants of less than 1 year where $15 \%$ of the children with atopic eczema mounted IgE autoreactivity and raised in the age group of 2-13 years with moderate to severe AE and total IgE serum levels higher $1,000 \mathrm{kU} / \mathrm{L}$ up to $80 \%$ (46).
TABLE 1 | Percentage of patients in which immunoglobulin $E$ (lgE) autoantibodies have been detected in various diseases.

\begin{tabular}{|c|c|c|c|}
\hline Disease & IgE against & Prevalence & Reference \\
\hline $\begin{array}{l}\text { Allergic } \\
\text { rhinoconjunctivitis }\end{array}$ & Profilin & & $(16)$ \\
\hline Asthma & n.a. & n.a. & $(17,18)$ \\
\hline Atopic dermatitis & $>140$ lgE-binding self-antigens & $23-91 \%$ & $(19,20)$ \\
\hline $\begin{array}{l}\text { Autoimmune } \\
\text { pancreatitis }\end{array}$ & n.a. & n.a. & (21) \\
\hline $\begin{array}{l}\text { Bullous } \\
\text { pemphigoid }\end{array}$ & BP 180 or 230 & $22-100 \%$ & (22) \\
\hline $\begin{array}{l}\text { Chronic } \\
\text { spontaneous } \\
\text { urticaria }\end{array}$ & $\begin{array}{l}\text { Thyroidperoxidase (TPO), } \\
\text { double stranded DNA (dsDNA), } \\
\text { IL-24 }\end{array}$ & $0-80 \%$ & (23) \\
\hline Graves disease & TPO, muscle autoantigens & $67 \%$ & $(24,25)$ \\
\hline $\begin{array}{l}\text { Multiple sclerosis } \\
\text { (MS) }\end{array}$ & $\begin{array}{l}\text { Small myelin protein-derived } \\
\text { peptides }\end{array}$ & n.a. & (26) \\
\hline Pemphigus & $\begin{array}{l}\text { Desmoglein1, Desmoglein 3, } \\
\text { Lamininin-332 und LJM11 }\end{array}$ & $11-81 \%$ & (22) \\
\hline $\begin{array}{l}\text { Rheumatoid } \\
\text { arthritis }\end{array}$ & ANA, anti-citrullinated protein? & $60 \%$ & (27) \\
\hline $\begin{array}{l}\text { Systemic lupus } \\
\text { erythematodes and } \\
\text { lupus nephritis }\end{array}$ & $\begin{array}{l}\text { dsDNA, Sm, SS-A/Ro, SS-B/ } \\
\text { La, APEX, MPG, CLIP4, ANA, } \\
\text { RNP, nucleosome, specific IgE, } \\
\text { acidic ribosomal } P_{2} \text { protein }\end{array}$ & $3.6-82 \%$ & (28) \\
\hline Uveitis & Retinal S antigen & $69 \%$ & (29) \\
\hline
\end{tabular}

n.a., not assessed.

\section{Systemic Lupus Erythematosus}

In SLE, several IgE autoantigens have been described $(28,47)$, and their occurrence is frequent. In a study of 92 SLE patients (48), 29 (32\%) had antinuclear-IgE antibodies. No such antibodies were found in a parallel healthy control group. Sub-analysis of the IgE autoantibodies in the 29 positive patients showed reactions with nucleosomes (79.3\%), double stranded DNA (dsDNA) (48.3\%), SS-A/Ro (48.3\%), SS-B/La (18.7\%), Sm (48.3\%), and RNP (62.1\%). In a multicentre study of 196 SLE patients (49), more than $50 \%$ showed autoreactive IgE to one or more of the four common SLE nuclear autoantigens, dsDNA, SS-A/Ro, SS-B/La, and Sm. This figure rose to around $74 \%$ in patients with active disease where autoreactive IgE to dsDNA was most prevalent with an incidence of $63 \%$. From these findings, Dema and colleagues (49) suggest that the presence of autoreactive IgE, and in particular dsDNA-specific IgE, in SLE, may be a reasonable clinical indicator of increased disease activity. This conclusion is supported by a study that showed that disease flares rates were higher in SLE patients with demonstrable circulating IgE-antidsDNA antibodies than in those without (50).

Because approximately half of SLE patients do not have demonstrable IgE antibodies to the common nuclear autoantigens, the prevalence of IgE autoantibodies to other autoallergens has been explored. One study showed high levels of IgE autoantibodies to APEX nuclease 1, N-methylpurine-DNA glycosylase and CAP-Gly domain-containing linker protein family member 4 in some SLE patients but not healthy controls. These autoantigens were unique in that they seemed specific targets of IgE autoantibodies but not autoantibodies of the IgG class (49). In another study, 31\% of 90 SLE patients displayed IgE antibodies against human $\mathrm{P} 2$ proteins, an antigen that has also been described to be 
cross-reactive with other members of the ribosomal P 2 protein family, which are minor allergens in fungal allergy (51).

Finally and importantly, IgE to Ro/SSA, a ribonuclearprotein autoantigen has been suggested to be relevant for fetal loss by mothers with SLE (52). This is of special interest as IgG-anti-Ro/ SSA antibodies are known to be associated with neonatal lupus (congenital heart block, neonatal transient skin rash, hematological and hepatic abnormalities). However, they are suggested not to negatively affect other gestational outcomes, and the general outcome of these pregnancies is good when managed by experienced multidisciplinary teams (53).

\section{Bullous Pemphigoid}

Bullous pemphigoid is an autoimmune blistering disease that mainly affects elderly patients. It is the most common pemphigoid disorder accounting for around $80 \%$ of all pemphigoid cases (28). IgG, IgA, and IgE autoantibodies are directed against two hemidesmosomal proteins, the transmembrane protein BP antigen 2 (BP180, type XVII collagen) and the intracellular BP antigen 1 (BP230) $(22,54,55)$. Binding of autoantibodies leads to a complex inflammatory response involving complement activation, the infiltration of inflammatory cells, and the subsequent release of reactive oxygen species and distinct proteases that finally mediate subepidermal splitting (56).

Immunoglobulin E autoantibodies against BP180 target mainly the 16th non-collagenous domain (BP180 NC16A) (54, 57) although BP180 epitopes outside the NC16A domain have also been described to be recognized by IgE (58). That IgE-anti-BP180 is functional was demonstrated by the ability of serum from BP patients to sensitize mast cells and basophils for BP180-induced histamine release (59). The percentage of BP patients with IgEanti-BP180 autoantibodies, shown in Table 2 , varied substantially in the different reports. The reason in this variation is likely to be due to the different test systems used, i.e., ELISA or immunoblotting, and the use of diluted or undiluted patient sera.

Several studies were able to detect IgE autoantibodies against the intracellular BP230 autoantigen. Engineer et al. reported IgE-anti-BP230 without detection of BP180-specific IgE autoantibodies in $100 \%$ of six BP patients (67). In contrast, other studies revealed IgE-anti-BP230 and IgE-anti-BP180 autoantibodies in $67 \%$ of 67 sera (61) and $50 \%$ of 32 sera (68). IgE-anti-BP230 reactivity was associated with local eosinophil accumulation (61),

TABLE 2 | Percentage of patients with bullous pemphigoid showing immunoglobulin E (lgE) reactivity to BP180.

\begin{tabular}{lcc}
\hline Number of patients & Percentage with IgE-anti-BP180 & Reference \\
\hline 37 & 22 & $(60)$ \\
67 & 30 & $(61)$ \\
117 & 40 & $(56)$ \\
44 & 41 & $(62)$ \\
18 & 55 & $(63)$ \\
31 & 61 & $(64)$ \\
56 & 71 & $(65)$ \\
43 & 77 & $(58)$ \\
18 & 83 & $(66)$ \\
10 & 100 & $(54)$
\end{tabular}

with disease activity (69) and correlated with total IgE serum levels $(68,70)$.

\section{Other Autoimmune Blistering Disorders}

Pemphigus vulgaris (PV) is another severe autoimmune bullous skin disease and is primarily associated with IgG against desmoglein 3 (dsg3), a desmosomal adhesion protein. However, raised IgE in these patients has also been reported (71). Intercellular $\operatorname{IgE}$ deposits were detected in the epidermis of 37 patients with acute onset of the disease, and IgE-anti-dsg3 was detected more frequently in the sera of patients with acute onset, compared to chronic-active PV (72). Spaeth and colleagues reported dsg3reactive IgE in the serum of $13 \%$ of 15 patients with acute onset, $11 \%$ of 18 patients with chronic-active, and none of 8 patients with remittent PV patients (73).

In mucus membrane pemphigoid, one of four patients showed IgE reactivity to the gamma2 subunit of laminin-332 (74). In endemic pemphigus foliaceus, IgE-anti-desmoglein 1 was found in $81 \%$ of 143 patients with fogo selvagem (75), and serum levels of IgE against LJM11, a major immunogenic component of sand fly salivary gland antigens, were significantly higher compared to controls (76).

In summary, reports in pemphigus are limited, but IgE reactivity seems to be more prevalent in the endemic form of pemphigus foliaceus than in PV.

\section{Chronic Urticaria}

An important role of IgE and FceRI reactions was postulated in both CSU and CindU for several decades (77) before it was finally confirmed by the successful treatment of the disease with anti-IgE (omalizumab) $(14,15,78)$. Although specific IgE against classical common allergens, i.e., aeroallergens and food allergens (79-82), or to less common allergens such as fungi $(83,84)$ can be detected in some patients with CSU, they are not regarded as pathophysiologically relevant for the development of the signs and symptoms of CSU (81, 85-87).

Perhaps the first evidence of autoreacitivitiy in CSU came with the clinical observation that CSU patients have high rates of thyroid diseases (88). Detailed analysis of CSU patients with thyroid pathology led to the detection of IgE anti-thyroidperoxidase (TPO) autoantibodies. Almost 20 years ago, Bar-Sela and coworkers reported the detection of IgE-anti-TPO in a female CSU patient who also had Hashimoto's thyroiditis (89). More recently, elevated levels of IgE-anti-TPO were reported in $61 \%$ of 478 CSU patients (13). However, other studies found only $13-17 \%$ of 23 patients (90) and $10 \%$ of 20 patients (91) to have IgE-antiTPO, while a further study failed to find IgE-anti-TPO in $23 \mathrm{CU}$ patients (92). The most likely explanation for these differences is the use of different assay systems, for example direct ELISA vs capture ELISA, and the interference of IgG autoantibodies against TPO (93). Functional relevance was suggested as flow cytometry analysis showed CD203c induction in a dose-dependent manner in basophils sensitized with serial additions of TPO in CU patients having high specific IgE to TPO (94).

Beside thyroid diseases, the prevalence of individual autoimmune diseases in chronic urticaria is increased in general $(\geq 1 \%$ in most studies vs $\leq 1 \%$ in the general population). In a review, 
the rates of comorbidity were $\geq 1 \%$ for insulin-dependent diabetes mellitus, RA, psoriasis, and celiac disease, $\geq 2 \%$ for Graves' disease, $\geq 3 \%$ for vitiligo, and $\geq 5 \%$ for pernicious anemia and Hashimoto's thyroiditis. Interestingly, $>15 \%$ of CSU patients have a positive family history for autoimmune disease (95).

A recent review investigated also the correlation of chronic urticaria with other autoimmune diseases such as SLE. The prevalence of CSU and CSU-like rash in SLE was investigated from 42 independent studies. Comorbidity in adult patients reportedly ranged from 0 to $22 \%$ and 0.4 to $28 \%$, respectively (urticarial vasculitis: 0-20\%). In children with SLE, CSU was reported in 0-1.2\% and CSU-like rash in 4.5-12\% (urticarial vasculitis: 0-2.2\%) (96). Specifically, significantly higher levels of IgE-anti-dsDNA, but not corresponding IgG levels, have also been found in a study of 85 chronic urticaria patients (97). Furthermore, basophils from 2 out of 9 of these patients exhibited degranulation in response to dsDNA, indicating functional relevance of these autoantibodies.

Beside these IgE antibodies that target antigens known in autoimmune diseases, patients with CSU can also develop IgE autoantibodies against probably disease-specific antigens. Schmetzer et al. found more than $200 \mathrm{IgE}$ autoantigens in patients with CSU that were not found in healthy controls (98). Of the 31 IgE autoantigens detected in more than $70 \%$ of patients, 8 were soluble or membrane-bound and expressed in the skin and IgE autoantibodies to IL-24 were found in all patients with CSU. In vitro studies showed functional relevance, and clinically IgE-anti-IL-24 levels showed an association with disease activity. Detailed analysis of the remaining identified IgE targets had not been provided yet.

\section{Other Diseases}

In many diseases, single or few reports have indicated a presence or potential role of autoreactive $\operatorname{IgE}$.

\section{Autoimmune Uveitis}

Beside IgG autoantibodies, in autoimmune uveitis specific IgE to retinal S antigen was positive in $69 \%$ of 32 patients. In contrast, patients suffering from bacterial uveitis, as well as the healthy controls were negative for autoantibodies to retinal S antigen (29). Furthermore, IgE, IgG, and IgA anti-Galectin-1 (Gal-1) antibodies were increased in sera from patients with autoimmune uveitis and toxoplasmic retinochoroiditis compared to healthy controls (99). Both, anti-Gal-1 IgE and IgG antibodies were associated with progressive disease and poor disease outcome.

\section{Rheumatoid Arthritis}

A role of IgE antibodies in RA was first suggested several decades ago $(27,100)$. Antinuclear antibodies of the IgE class were found in $60 \%$ of 20 RA patients with neutropenia, whereas only $16 \%$ of RA patients without neutropenia had IgE antibodies of similar specificity (27). Anti-citrullinated protein antibodies are suggested to be highly specific and predictive for RA. In a study from Schuerwegh and colleagues, evidence for IgE directed against citrullinated protein was proposed (101), but later the paper was retracted (102). In recent times, no valid studies regarding this topic have been published.

\section{Multiple Sclerosis}

A role of IgE antibodies in the disease was suggested, despite the fact that there was no association between MS and allergies (103). In a study from Mikol and colleagues in 26 MS patients, a total of 128 peptides showed some IgE reactivity (mean 4.9 per subject), compared to 59 among the 15 controls (mean 3.9 per subject) (26). A detailed analysis of short, unique myelin proteinderived peptides (SUMPPs) revealed that for several SUMPPs, MS patients had significantly more reactive IgE, whereas for other SUMPPs, there was no significant difference between MS subjects and controls. The authors speculated that IgE reactive against CNS target antigens may have diagnostic and pathogenic significance.

\section{Hyperthyroid Graves' Disease}

The presence of IgE autoantibodies in Grave's disease was first proposed 40 years ago (104). Elevation of serum IgE $\geq 170 \mathrm{U} / \mathrm{mL}$ was found in up to $36 \%$ of the patients (105-108), but not in another study (109). Furthermore, there was immunohistochemical evidence for IgE involvement in Graves' orbitopathy (110). Studies regarding specific IgE autoantibodies in thyroid disease showed IgE class TPO autoantibodies in 13 of 18 Graves' and in 12 of 17 Hashimoto patients (24) and muscle autoantigens in thyroid associated ophthalmopathy (25). Evidence for a functional relevance of these $\operatorname{IgE}$ autoantibodies was shown by Raikow and colleagues, who showed that serum IgE is elevated in connection with certain stages of rapid dysthyroid orbitopathy progression (111).

\section{Autoimmune Pancreatitis}

Elevated total IgE levels are frequent in patients with autoimmune pancreatitis $(21,112)$, and it was recently suggested that analysis of total IgE in serum might be useful in the differentiation between autoimmune pancreatitis and pancreatic carcinoma (113). Nevertheless, IgE specific targets remain currently unknown, although there may be cross-reactivity with environmental antigens, as patients with higher IgE levels and with allergic diseases were more likely to have onset in March, April, May, August, September, or October (21).

\section{Asthma}

Autoallergic mechanisms have been proposed in murine models of asthma $(17,114)$. In human asthma, approximately $50 \%$ of patients with non-allergic asthma react to intradermal injection of autologous serum, indicating the presence of circulating vasoactive factors and suggesting the possibility of an autoreactive mechanism (18). In one patient with corticosteroid-dependent asthma associated with aspirin sensitivity, the presence of circulating IgE antibodies against 55 and $68 \mathrm{kDa}$ platelet antigens has been described (115). Overall, autoallergy in asthma has not been studied in detail in humans so far.

\section{Allergic Rhinoconjunctivitis}

There is very limited evidence for IgE autoreactivity in allergic rhinoconjunctivitis. IgE antibodies from allergic individuals that bind to natural and recombinant birch profilin also bind 
to human profilin (16). Similar cross-reactivity was shown for human acidic ribosomal P2 protein in individuals sensitized to Aspergillus fumigatus $\mathrm{P} 2$ protein (116).

\section{Diseases in Which IgE Autoantibodies Were Looked for but Not Found}

In chronic rhinosinusitis with nasal polyps no IgE autoreactivity to epithelial antigens, or anti-IgE IgG, has been detected, despite extensive tests (117).

\section{WHAT DO WE KNOW ABOUT THE RELEVANCE OF IgE AUTOANTIBODIES IN DIFFERENT DISEASES?}

IgG-mediated autoimmune diseases occur in up to $9 \%$ of the population (118). Whether or not other immunoglobulin subtypes, including IgE, are critically involved in the pathogenesis of autoimmune diseases is largely unknown for most diseases. In contrast, polyreactive natural antibodies, which are not antigenspecific, can often detect self-antigens with low affinity. Most of these natural antibodies belong to the isotypes $\operatorname{IgM}, \operatorname{IgG}_{3}$, and $\operatorname{IgA}$, and these unspecific antibodies, even if they can bind to self-antigens, are thought to be protective, rather than harmful $(119,120)$. There is also some published evidence for the existence of natural IgE antibodies against pancreatic cancer cells (121) and conserved biotinylated-enzyme molecules present in many organisms, such as Anisakis simplex, Toxocara canis, Ascaris suum, and Culex quinquefasciatus $(122,123)$. While there are currently no data available on the role and relevance of natural $\operatorname{IgE}$ antibodies and how they could affect disease activity, there is some published evidence for a role of antigen-specific IgE against self in different diseases. For some diseases, there is only a single report on the potential role for auto-IgE. As reviewed above, in $\mathrm{PV}$, high concentrations of serum IgE autoantibodies have been detected, and a strong correlation between dsg3-reactive IgE has been observed in patients with acute disease onset, indicating a role for auto-IgE in pemphigus (72). In patients with MS, there are some data indicating that IgE against CNS target antigens may have a pathogenic significance, particularly if other peptidespecific, potentially blocking immunoglobulins are absent (26). In other autoimmune diseases or diseases in which autoimmunity is thought to play a role, some more information on the potential role of auto-IgE has been published.

\section{Atopic Dermatitis}

Although the pathogenesis of $\mathrm{AD}$ is still not completely understood, it is generally accepted that the underlying etiology is multifactorial, including environmental factors, impaired skin barrier function, and a hyper-immune activation (124). The role and relevance of autoimmunity in $\mathrm{AD}$ is as of yet unclear. In $\mathrm{AD}$ patients, many autoantigens can be detected, and IgE against self is highly prevalent $(125,126)$. Whether these auto-IgE antibodies indeed contribute to disease activity and severity or are merely bystanders cannot be concluded at present $(125,126)$. There is some evidence, however, that is suggestive of a pathogenic role for IgE against self in AD. Tang and colleagues have summarized this evidence and conclude that $\operatorname{IgE}$ autoreactivity is of importance in the pathogenesis of $\mathrm{AD}$, especially because autoreactivity has been identified in various in vitro and direct clinical experiments across distinct study populations (19). Furthermore, significant associations between auto-IgE levels in $\mathrm{AD}$ patients and disease severity have been reported $(37,38)$, while a further two reports show a trend, but no significance for such a correlation $(41,46)$. In contrast, one investigation did not identify a correlation (39).

If auto- $\operatorname{IgE}$ is importantly involved in $\mathrm{AD}$ pathogenesis, treatment with anti-IgE antibodies should be able to improve symptoms. Because of the above mentioned investigations, omalizumab has been widely used in treatment refractory AD patients and many case reports and case series have been published. Two recent systematic reviews on the use of omalizumab in $\mathrm{AD}$ both come to the conclusion that anti-IgE treatment can be beneficial in the treatment of $\mathrm{AD}$, but that larger clinical trials are missing to fully support this statement $(127,128)$.

\section{Systemic Lupus Erythematosus}

Autoreactive IgE against a number of different antigens has been reported in SLE (see respective section above). In many investigations, a close correlation between levels of auto-IgG and autoIgE in the same patients has been shown, making it difficult to estimate the contribution of auto-IgE to the pathology of SLE (49, $51,129,130)$. However, Henault and colleagues reported that the concentration of IgE anti-dsDNA correlates with disease severity and is likely to contribute to disease pathology independent from IgG anti-dsDNA (129). Dema and colleagues similarly show an association of the levels of IgE against different autoantibodies with SLE, comparable to autoreactive IgG levels (49). The best prediction of disease activity was found to be the presence of both, dsDNA-specific IgE and IgG, possibly indicating a role for auto-IgE in SLE (49).

In a recent publication, Pan and colleagues have shown that SLE patients not only have high levels of IgE directed against various autoantigens but also strongly decreased numbers of circulating basophils, suggesting auto-IgE-dependent basophil activation in the blood (131). These authors also stated that basophils from SLE patients showed high rates of activation that closely correlated with SLE activity. How this correlates with disease mechanisms is not clear. Anti-IgE treatment has not been reported in SLE patients as of yet.

\section{Bullous Pemphigoid}

The largest body of evidence for a pathological role of autoreactive IgE in the literature can be found for BP. In those patients presenting with specific IgE directed against the autoantigen BP180, a correlation of auto-IgE and disease severity has been reported $(56,60,63)$. Moreover, Freire and colleagues have shown that IgE-anti-BP180 cannot only be found in the serum of BP patients, but also in the skin, bound to the surface of tissue-resident mast cells (132). Furthermore, they show that patient-derived IgEanti-BP180 complexes can activate basophils, indicating the functionality of these antibodies (132).

In a number of case reports and case series, excellent efficacy of treatment with omalizumab has been shown in BP patients (133-140). While these findings are highly suggestive of a 
pathogenic role for auto- $\mathrm{IgE}$ in $\mathrm{BP}$, controlled clinical trials with omalizumab in BP are necessary to prove the efficacy of anti-IgE treatment and thus of the relevance of auto-IgE in BP.

\section{Chronic Urticaria}

The evidence for a pathogenetic role of auto-IgE in chronic urticaria has been extensively discussed in a recent review (141). This paper concluded that there are still many aspects of the pathologic mechanisms of CSU that need to be resolved, but that it is becoming increasingly clear that there are at least two distinct pathways, type I (IgE-mediated) and type II (IgG-mediated) autoimmunity, both of which contribute to the pathogenesis of this complex disease.

Since then, further evidence for a role for auto-IgE in CSU has been presented by Schmetzer and colleagues. Overall, more than 200 autoantigens that are recognized by $\operatorname{IgE}$ have been detected in CSU patients, and in $80 \%$ of more than 1,000 CSU patients, IgE-anti-IL-24 was present (98). Furthermore, levels of IgEanti-IL-24 in the serum correlated with CSU disease activity, and ex vivo, IL-24 was able to activate mast cells after pre-incubation with serum from IgE-anti-IL-24 positive patients, indicating a biological relevance for IgE-anti-IL-24 in CSU patients (98).

The clinical relevance of IgE in both CSU and CindU has been proven in numerous case reports and case series and in a number of randomized-controlled trials using the anti-IgE antibody omalizumab (142-145). In fact, the first multi-center placebocontrolled study of omalizumab in CSU, the XCUISITE trial, was done in CSU patients who had IgE-anti-TPO (146). In this trial, $70 \%$ of patients of omalizumab-treated patients, but only $5 \%$ of placebo-treated patients experienced complete protection from wheal development, and the onset of omalizumab effects was early after the initiation of treatment. This strongly argues that the rapid and profound neutralization of auto-IgE by omalizumab contributed to its effects and that these IgE autoantibodies play a role in the pathogenesis of CSU. Further support for this comes from a recent study that showed that serum reactivity predicts the time to response to omalizumab therapy in CSU patients (147), suggesting that patients with IgG autoantibodymediated CSU show delayed responses, whereas patients with IgE-autoantibody-mediated CSU have fast onset of improvement. The exact mechanisms by which anti-IgE treatment leads to the resolution of symptoms in most CSU patients are, as of yet, unclear. Nonetheless, at least in a proportion of CSU patients, the massive reduction of autoantigen-specific IgE is likely to be the most relevant mechanism.

In CindU, there is also a strong indication for an important role of IgE against self. For example, anti-IgE treatment has been shown to be highly effective in CindU in numerous case reports and case series, as well as in two randomized-controlled trials (Table 3). Furthermore, a direct involvement of IgE in some patients with CindU has been shown by passive transfer experiments. In cold urticaria $(148,149)$ as well as in symptomatic dermographism (150) disease activity was, in some patients, transferable from patients to healthy subjects by intradermal injection of patient sera. In these investigations, IgE was identified to be the relevant serum factor (148-150).
TABLE 3 | Summary of chronic inducible urticaria patients showing a complete or partial response to omalizumab reported in case reports, case series, and clinical trials.

\begin{tabular}{lccc}
\hline Condition & $\begin{array}{c}\text { Total } \\
\text { patients }\end{array}$ & $\begin{array}{c}\text { No. of } \\
\text { responders }\end{array}$ & $\begin{array}{c}\text { Percentage } \\
\text { responders }\end{array}$ \\
\hline Symptomatic dermographism & 58 & 43 & 74 \\
Cold urticaria & 51 & 39 & 76 \\
Solar urticaria & 47 & 34 & 72 \\
Delayed pressure urticaria & 32 & 29 & 91 \\
Cholinergic urticaria & 21 & 17 & 81 \\
Heat urticaria & 5 & 3 & 60 \\
Vibratory angioedema & 1 & 0 & 0 \\
Aquagenic urticaria & 1 & 1 & 100 \\
Total & 216 & 166 & 77 \\
\hline
\end{tabular}

Data contained in this table were obtained from Ref. (145, 151-153).

\section{WHAT DO WE KNOW ABOUT THE GENETIC BASIS OF IgE-MEDIATED AUTOALLERGY}

In an effort to understand the genetic influence on autoallergic diseases, it is best to look first at well-analyzed diseases such as SLE, where autoreactive IgE has been known for four decades (27). The prevalence of SLE and the presence of new autoreactive IgE are remarkably dependent on sex and race being 2.3-fold higher in Black persons than in White persons and 10-fold higher in females than in males (154). The greater incidence in females may be partially explained by the observation that women treated with estrogen and progesterone have a 1.34 times higher risk of developing SLE flares as compared to placebo treated.

Autoreactive IgE has been assessed in two SLE patient cohorts, IgE targeting classical SLE antigens being found in $63.3 \%$ of patients of French origin but only $52.9 \%$ of the patients from the United States (49). Most prominent in this study was IgEanti-dsDNA but also auto-IgE against other SLE antigens (Sm, SSA/Ro, SSB/La). Non-SLE IgE only antigens (APEX, MPG, CLIP4) were also found. This autoreactive IgE correlated highly significantly with disease activity (SLEDAI score) and reduced C3 or C4 levels suggesting that IgE facilitates the amplification of autoimmune inflammation (155).

Chronic spontaneous urticaria is another example of an autoIgE-mediated disease, where a strong and complex genetic bias via multiple alleles exists. These include C5AR1 (156), FPRL1 (157), FcvarepsilonR1beta (158), TGFbeta1 (159, 160), IgE (161), IL-13 (162), histamine N-methyltransferase (163), PTPN-22 (164, 165), CTLA-4 (166), and ACE (167).

In addition to the well-known loci linked to hypersensitivity and atopy, such as PLA2G7, MS4A2, IL4R (168), IL-10 (169), IL12RB1 (170), STAT4/6, CTLA-4 (171), and GATA3 (172), recent studies identified many new alleles which regulate IgE production independent of external stimuli. However, these are often single findings, and only a genome-wide screening could weigh these findings and determine their relation to atopy, $\operatorname{IgE}$ and auto-IgE. One genome-wide screening on alleles influencing total IgE level identified FCER1A polymorphisms as having most impact, followed by RAD50 and STAT6 as the lowest relation (173). 
One genetic variant has been studied in detail which links elevated IgE concentrations to a polymorphism in the IL21R gene promoter (174). This $-83 \mathrm{~T}-\mathrm{C}$ promoter polymorphism in the $I L 21 R$ gene is linked to a changed response of IgE synthesis to IFN-gamma stimulation (175). If $I L-21$ is knocked-out in murine models, IgE production after immunization is increased, while IgG subtypes are decreased in otherwise normal animals (176). In contrast, loss-of-function of the $I L-21 R$ gene in humans leads to a severe primary immune defect (177). The difference to the murine model is not surprising, given the low degree of homology of the IgE system between man and rodent.

In addition to this $I L-21$ gene variant, environmental receptor encoding genes, such as NOD1 have been linked to asthma (178). This opens a crucial new viewpoint on genetics where environmental stimuli are related to selected genotypes to explain the phenotype. Another example is the $\beta 2$-adrenoreceptor gene promoter polymorphism that determines modulation of $\operatorname{IgE}$ production as a response to xenobiotics ( $\beta 2$-agonists and glucocorticoids) (179).

These examples demonstrate the vast complexity of the genetic regulation of IgE synthesis (180). With modern deep sequencing strategies there are more and more variants found which change the risk for asthma and atopy, and influence IgE level. Sequencing of the IL4 gene alone lead to 14 new, previously unrecognized polymorphisms in addition to only two known previously (181). There are no studies on auto-IgE and HLA polymorphisms. However, IgE is involved in antigen uptake via immune complexes and presentation via MHC class II to CD4 cells $(44,182$, 183). Therefore, there is a high likelihood that HLA genotypes will be linked to auto-IgE, but the studies need to be done.

\section{WHAT DO WE KNOW ABOUT THE CELLULAR AND MOLECULAR EFFECTS OF IgE AUTOANTIBODIES?}

When looking on the effects of IgE autoantibodies, mast cells and basophils are usually the focus of attention as they express high levels of the high-affinity receptor for IgE (FceRI). Antigendependent activation of mast cells and basophils via FceRI is the cause of acute allergic reactions induced by the rapid release of preformed mediators from granules and subsequent liberation of de novo synthesized lipids, cytokines, and chemokines. Yet, mast cells and basophils are not the only cells that express FceRI and, importantly, other receptors such as CD23 (FceRII) and galectin-3 are capable of binding IgE and inducing cellular responses. Thus, mast cell and basophil activation may be only the tip of the iceberg when considering the biology of $\operatorname{IgE}$ autoantibodies and their contribution to diseases. In particular, the function of CD23 in IgE-dependent sensitization of the host to autoallergens, which in turn may further strengthen the production of autoreactive IgE might be of great importance in the development of autoallergies.

In general, all IgE, whether it is autoreactive or whether it recognizes exogenous antigens, can trigger the same cellular responses as there is no evidence yet that autoreactive $\operatorname{IgE}$ have special molecular characteristics that drive certain functions/ responses such as, for instance, cytokinergic activity. However, certain activities are not necessarily triggered by autoreactive IgE such as the CD23-mediated transepithelial transport of IgE. Here, we will focus on IgE-binding receptors with regards to their contribution in autoallergy.

\section{Effects of IgE/Autoantigen on FceRI Signaling}

The high-affinity receptor for $\operatorname{IgE}$ (FceRI) consists of one IgE-binding $\alpha$ chain, which binds IgE with a very high affinity $\left(10^{10} \mathrm{M}^{-1}\right)$, but does not contain intracellular signaling motives, one transmembrane-spanning $\beta$ chain, which crosses the plasma membrane four times and contains an immunoreceptor tyrosine-based activation motive (ITAM), and two identical $\gamma$ chains each containing an ITAM (184). This $\alpha \beta \gamma \gamma$ motive is mainly expressed by mast cells and basophils although expression has also been shown in airway smooth muscle cells and bronchial epithelial cells of asthmatic patients (185, 186). A $\alpha \gamma \gamma$ version of this receptor can be expressed by a variety of other cells including subsets of dendritic cells and monocytes/ macrophages (187-189), eosinophils (190), neutrophils (191), and platelets $(192,193)$. Because of its high affinity for IgE, the receptor is occupied by monomeric IgE. When cross-linked by a multivalent antigen, it triggers signaling cascades leading to the immediate degranulation in mast cells and basophils, i.e., the release of preformed mediators from intracellular granules and de novo synthesis of lipid mediators such as prostaglandins and leukotrienes as well as the production of cytokines and chemokines and the expression of various surface markers. These include chemokine receptors such as CCR7 on plasmacytoid dendritic cells (pDCs) (129) or the selectin CD62L on basophils (194) that facilitate the migration of activated cells to local lymph nodes, but also co-stimulatory molecules like CD83 and CD86 on pDCs. Moreover, autoreactive IgE activates pDCs more efficiently and further synergizes with IgG through co-engagement of activating Fc $\gamma$ RIIa, even in concentrations several orders of magnitude below IgG concentrations and drive B cell expansion and plasma call differentiation $(129,130)$. FceRI engagement by IgE and allergen also induces IL-16 in Langerhans cells, a chemoattractant for CD4+ T cells, dendritic cells, and eosinophils (195). Thus, autoreactive IgE may have the capacity to augment disease activity in autoimmunity.

Surface bound IgE has been shown to stabilize and enhance the surface expression of FceRI on mast cells and basophils, thereby allowing cells to bind more IgE, which in turn may lower the threshold for antigen-induced cell activation (196). This amplification loop might be of particular importance in autoallergic patients who present with increased serum and tissue IgE levels. Consistently, treatment with antibodies directed against IgE does not only lower serum IgE levels but also FceRI surface expression on dendritic cells, basophils, and mast cells (197-199). Moreover, FceRI-bound IgE promotes mast cell survival and migration (200). Interestingly, certain IgEs even induce mast cell and basophil degranulation and cytokine release in an antigen-independent manner (201). Although the in vivo relevance of this "cytokinergic" activity 
has not been demonstrated yet, it may have an impact in autoallergy. Cytokinergic IgE molecules associate with themselves and show an enhanced propensity to be polyreactive to various autoantigens $(202,203)$.

FceRI-bound and antigen cross-linked IgE becomes internalized rapidly $(129,204)$. Thus, on the one hand, free serum $\mathrm{IgE}$ is cleared by dendritic cells and monocytes. On the other hand, when cross-linked, autoantigens become internalized and are capable of stimulating intracellular pattern recognition receptors such as TLRs. In pDCs, IgE autoantibodies directed against dsDNA become internalized and directed to phagolysosomes where TLR9 becomes activated to trigger the generation of inflammatory cytokines, such as INF- $\alpha$, IL- 6 , IL-8, and TNF- $\alpha$ (129). Alternatively, internalized IgE/autoantigen is presented via MHC class-II by basophils, cutaneous Langerhans cells, or other dendritic cells in regional lymph nodes or local submucosal sites to naïve $\mathrm{T}$ cells to induce $\mathrm{T}_{\mathrm{H}} 2$ cells $(194,196,205,206)$. In systemic lupus erythematosus (SLE), activation of basophils by autoreactive IgE can induce the upregulation of CD62L, MHC-II and the B cell-activating factor BAFF. Activated basophils then migrate into the secondary lymphoid organs, where they produce IL-4 and IL-6, thereby promoting a $\mathrm{T}_{\mathrm{H}} 2$ environment with more IL- 4 producing activated $\mathrm{T}$ cells and enhanced $\mathrm{B}$ cell proliferation with increased $\operatorname{IgG}_{1}$ and $\operatorname{IgE}$ production (194). In addition, CD1c+ dendritic cells may have the capacity for cross-presentation of internalized antigen to induce cytotoxic CD8+ cells. However, this is strongly inhibited by IL-4-producing $\mathrm{T}_{\mathrm{H}} 2$ cells (207). On monocytes, the engagement of FceRI induces antibodydependent cell-mediated cytotoxic activities of the cells rather than antibody-dependent cell-mediated phagocytic activities (ADCP), which are linked to the engagement of the lowaffinity IgE receptor, CD23 (see below).

In $\mathrm{BP}, \mathrm{CSU}$ and $\mathrm{AD}$, the degranulation of mast cells and basophils contributes to disease manifestations. This, however, does not occur in systemic lupus erythematosus patients, who lack classical allergic manifestations. A possible mechanism for this is the co-engagement of inhibitory receptors such as Fc $\gamma$ RIIb by autoreactive IgG in SLE (208). Moreover, crosslinking of FceRI in monocytes and dendritic cells induces "late" anti-inflammatory IL-10, which can attenuate basophil and dendritic cell activation and suppresses monocyte phagocytic activity (209-211). Additionally, in monocytes, FceRI engagement induces the upregulation of indoleamine 2,3-dioxygenase (IDO), which inhibits $\mathrm{T}$ cell proliferation and activates FOXP3+ regulatory $\mathrm{T}$ cells through the depletion of tryptophan (212).

A soluble version of FceRI consisting of a single a-chain has been described (213). How sFceRI is generated in vivo is not known so far. In vitro experiments suggest that it is generated during cellular FceRI engagement. sFceRI may bind to IgE with similar affinity as membrane-bound FceRI and, therefore, might serve as a soluble regulator of free IgE and IgE-mediated cellular activation. Binding in a $1: 1$ ratio to $\operatorname{IgE}$, it has the potential to prevent IgE from binding to the cellular receptor, and could negatively affect FceRI expression levels. In vitro and in vivo studies with $\mathrm{sFcERI}$ show inhibitory properties on mast cell and basophil degranulation (214). Its impact in autoallergy, however, needs to be determined.

\section{Effects of IgE/Autoantigen on CD23 (FceRII) Signaling}

Most studies on the effects of IgE-mediated responses focus on mast cells or basophils and FceRI signaling, as they are responsible for the immediate allergic response. However, the so-called "low affinity" receptor for IgE, CD23, has important functions in positively or negatively regulating IgE synthesis as well as antigen presentation to T cells (215). It is expressed on various cells including epithelial cells, activated B and T cells, Langerhans cells, plasma cells, monocytes, and eosinophils (196). CD23 belongs to the family of C-type lectins, which are calciumdependent carbohydrate binding structures and contain three lectin domains located on the C-terminal extracellular head of the molecule. Interestingly, binding of IgE to the head domains seems not to involve carbohydrate structures (216). Although the affinity of a single CD23 head for the IgE-Fc is comparably low, the combined interaction of all three heads with $\operatorname{IgE}$ results in an strong binding with an affinity $\left(10^{8}-10^{9} \mathrm{M}^{-1}\right)$ that is comparable to that of FceRI (215). Interestingly, CD23 is prone to shedding by disintegrin and metalloproteinase domain-containing protein 10 (ADAM10) resulting in various soluble forms (monomeric or trimeric with varying sizes), all of which are capable to bind IgE $(214,217)$ and are found in autoimmune diseases like SLE where auto-IgE has been described (218). Multiple ligands/interaction partners other than IgE have been described to interact with CD23 and are important for its function including the complement receptor 2, 3, and 4 (CD21; CD18/CD11b; CD18/CD11c), $\mathrm{MHC}-\mathrm{II}$, the receptor for vitronectin ( $\alpha \mathrm{V} \beta 3$-integrin) and the $\alpha \mathrm{V} \beta 5$-integrin $(215,219)$. One important function of CD23 with regards to autoallergy is probably associated with the regulation of IgE production by B cells committed to IgE secretion. IgEinduced engagement of membrane CD23 induces a negative feedback while sCD23 (trimeric) through co-ligation of CD21 enhances IgE production (215). Moreover, CD23 bound IgEantigen complexes can be presented to T cells via a process called facilitated antigen presentation (FAP). In FAP, the antigen-loaded IgE-CD23 gets internalized and loaded onto MHC-II molecules for presentation on the B-cells surface (219). A Th2 environment, as derived by activation of mast cells and basophils via FceRII activation, may support this by increasing the expression of CD23 on B cells. Importantly, any activated B cell that expresses CD23, can present allergens to $\mathrm{T}$ cells independently of the specificity of the $\mathrm{B}$ cell receptor (BCR). By this, CD23-FAP can lead to epitope spreading, a process where the response to one epitope encountered by the BCR induces epitope-specific immunoglobulin production against the allergen internalized by CD23 (215). Epitope spreading can occur intra- or intermolecularly and is thought to be the driving cause for the development of polyspecific allergies to unrelated antigens. It is, therefore, of particular importance for the development of autoallergies. Antigen presentation via the CD23-MHC-II axis is as efficient as presentation of antigens by dendritic cells mediated by Fc $\gamma$ Rs and by far more efficient than BCR internalization (220). This is particularly dangerous when epitopes of an autoantigen and a pathogen are very similar 
in sequence and/or conformation (molecular mimicry) and IgE against the pathogen (IgE $\left.\mathrm{E}_{\mathrm{PATH}}\right)$ also binds to the autoantigen (221).

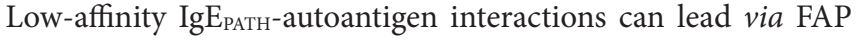
dependent epitope spreading to high affinity auto-IgE. For many autoimmune diseases, such as SLE and BP, where IgE autoantibodies have been identified, B cell epitope spreading has been recognized as an important contributor for disease development.

On monocytes and macrophages, engagement of CD23 induces nitric oxide synthase and proinflammatory cytokines and importantly mediates IgE-dependent phagocytosis of targeted cells suggesting a use for immunotherapy, for instance in cancer $(188,222)$. Interestingly, auto-IgE to tumor antigens can be found in tumor tissue as well as systematically, suggesting a tumor suppressive function of these IgE autoantibodies.

\section{Effects of IgE/(Auto)Antigen on Galectin-3 Signaling}

Galectin-3 is a secretory lectin containing a carbohydrate recognition domain connected to a non-lectin linker domain that associate to form a pentameric structure like IgM molecules. Galectin-3 is expressed by various immune cells including mast cells, basophils, neutrophils, monocytes, Langerhans cells, as well as $\mathrm{T}$ and B cells (196). It can be found in the nucleus, intracellular vesicles, or exosomes of expressing cells or gets secreted by a yet not fully characterized mechanism (223). Following secretion, it interacts with a large variety of cell surface and extracellular matrix proteins including IgE and FceRI. Interestingly though, galectin-3 appears to have distinct binding capacities for $\operatorname{IgE}$ isoforms that are differentially glycosylated, although the consequence of this phenomenon in allergy and autoallergy is not clear (224). Because it is capable of binding to IgE and FceRI, it can activate mast cells and other FceRI-expressing and/or IgEloaded cells in an IgE-dependent or independent manner and boost mast cell and basophil activation. In autoimmune diseases, galectin-3 is often increased in the serum and in tissues and may support auto-IgE-induced inflammation. However, most effects of galectin-3 on the immune system are independent of its ability to crosslink IgE and FceRI. Its effects and relevance in autoallergy, therefore, need to be determined carefully $(214,225)$.

\section{GAPS OF KNOWLEDGE, UNMET NEEDS, AND UNANSWERED QUESTIONS}

\section{Need for Improved Detection Methods}

There are two different major drawbacks of the tests currently used to assess autoreactive IgE. First, different methods show a high variability and low reproducibility of IgE reactivity (226). This has been best demonstrated using the well characterized BP autoantigen BP180-NC16A. An improved ELISA method showed a significantly higher frequency of NC16A-specific IgE autoantibodies in the sera of BP patients than previously described (66). This study also demonstrated that most BP sera contain both, IgE and IgG class autoantibodies specific for NC16A and that IgG reactive to the same autoantigen as $\mathrm{IgE}$ can mask the detection of autoreactive IgE. This is the second major drawback of direct ELISA methods. This problem can be addressed by the use of indirect ELISA methods, where total IgE is first captured on the plate by anti-IgE and labeled autoantigen is used for detection (98). This approach, however, also has limitations. Saturation of the anti-IgE with non-autoreactive IgE in sera with very high total IgE concentrations can lead to the underestimation of autoallergen-specific IgE. Also, this method requires recombinant IgE to be able to calculate the specific $\operatorname{IgE}$ concentration in international units.

Yet unaddressed questions are the relevance of different conformational states of IgE, such as the bent-form, that may not be detectable by ELISA depending on which anti-IgE is used (227). Relevant cross-autoreactive IgE might also be prone to oligomerization due to stacking, which may hinder binding to capture antibodies.

Finally, autoreactive IgE may be preferentially captured in the tissue in patients with high FceRI expression due to high IgE levels. Increased levels of IgE are frequently seen in patients with chronic urticaria and in atopic individuals $(228,229)$. Vice versa, as antigen reactivity encoded by the Fab-domain can change also the Fc part and, therefore, influence Fc receptor binding, some autoreactive IgEs might be over- or underrepresented in the noncell bound IgE fraction due to changed FceRI binding (230). Even assays detecting non-autoreactive IgE often fail to show a clinical relevance (231). The questions above need to be addressed for IgE in general, not only autoreactive IgE, in further studies, and improved methods need to be developed.

\section{What Leads to the Development of Autoantibodies of the IgE Isotype?}

There are several possible mechanisms that might lead to a preference of IgE isotype for autoantibodies. Most IgE autoantigens are phosphorylated molecules $(97,232,233)$. It has been demonstrated that IgG autoantibodies in BP preferably recognize a phosphorylated epitope $(232,234)$. The importance of phosphorylation for the development of autoantibodies in general has been shown for myeloperoxidase-anti-neutrophil cytoplasmic IgG autoantibodies in a mouse model (235). However, further studies are needed to assess whether this is a general rule preferably for IgE autoantigens, or for all autoantigens.

\section{IgE Cross-Reactivity Remains Largely Unexplained}

In contrast to $\operatorname{IgG}$ and $\operatorname{Ig} \mathrm{A}, \operatorname{IgE}$ has, in general, a much higher degree of cross-reactivity. This makes the determination of antigen-specific IgE difficult. As of now, very little is known about cross-reactivity of IgE autoantibodies. One study that performed site-directed mutagenesis of an allergenic peptide found that even after the mutation of all of the four residues that are mainly involved in IgE binding, the IgE still bound, albeit with a 100 -fold reduced affinity (236). Furthermore, many studies have shown IgE cross-reactivity to structurally similar allergens, e.g., sensitization to the fungus F. proliferatum may lead to allergy to penicillin (237).

Usually, IgE cross-reactivity is explained by the recognition of carbohydrate-containing epitopes such as in cross-reactive IgEs against wheat/pollen or latex/hymenoptera proteins (238-241) 
or between different pollen allergens (242-244). Hierarchies of cross-reactivity toward different pollen allergens have been established (245).

In latex-pollen-food allergy, a good example of noncarbohydrate based cross-reactivity, cross-reactive IgE binds to latex and maize (246) or other food allergens (247). The antigenic epitopes of these allergens are well characterized and show only a low degree of sequence homology. The cross-reactivity can only be explained by a similar charge distribution, which, in the case of IgG, does usually not lead to cross-reactive antibodies (248).

Other examples of IgE cross-reactivity include pollen-food allergy, such as apple-birch allergy or pollen-fruit allergy (249-253), dog-cat allergy $(254,255)$, poultry-meat allergy (256), fish-chicken allergy (257), birch-oak allergy (258), latex-hymenoptera allergy (239-241). IgE cross reactivity to latex and parasites like Schistosoma has also been described $(259,260)$. In mice sensitized to birch pollen that also developed anaphylactic reactions to apple, desensitization to birch pollen also provided protection from anaphylaxis to apple (261). Similar experiences have been reported in allergic patients, where tolerance induction against one allergen also reduced reactivity toward other allergens (262). While IgE cross-reactivity between classical allergens is much more common than previously thought (263), cross-reactivity between autoallergens needs to be investigated in future studies.

\section{REFERENCES}

1. Prausnitz C, Kustner H. Studien über die Ueberempfindlichkeit. Zentralbl Bakteriol (1921) 86:160-9.

2. Ishizaka $\mathrm{K}$, Ishizaka T. Identification of gamma-E-antibodies as a carrier of reaginic activity. J Immunol (1967) 99(6):1187-98.

3. Johansson SG, Bennich H. Immunological studies of an atypical (myeloma) immunoglobulin. Immunology (1967) 13(4):381-94.

4. Johansson SG. The history of IgE: from discovery to 2010. Curr Allergy Asthma Rep (2011) 11(2):173-7. doi:10.1007/s11882-010-0174-3

5. Marcolongo R, Marsili C. [Determination of serum $\operatorname{IgD}$ and $\operatorname{IgE}$ levels in patients with rheumatoid arthritis]. Reumatismo (1972) 24(2):173-4.

6. Hunder GG, Gleich GJ. Immunoglobulin E (IgE) levels in serum and synovial fluid in rheumatoid arthritis. Arthritis Rheum (1974) 17(6):955-63. doi:10.1002/art.1780170606

7. Marcolongo R, Marsili C. Serum $\operatorname{IgD}$ and IgE in rheumatoid arthritis. $Z$ Immunitatsforsch Exp Klin Immunol (1975) 148(4):285-90.

8. Arbesman CE, Wypych JI, Reisman RE, Beutner EH. IgE levels in sera of patients with pemphigus or bullous pemphigoid. Arch Dermatol (1974) 110(3):378-81. doi:10.1001/archderm.1974.01630090016003

9. Provost TT, Tomasi TB Jr. Immunopathology of bullous pemphigoid. Basement membrane deposition of IgE, alternate pathway components and fibrin. Clin Exp Immunol (1974) 18(2):193-200.

10. Ogawa M, Berger PA, McIntyre OR, Clendenning WE, Ishizaka K. IgE in atopic dermatitis. Arch Dermatol (1971) 103(6):575-80. doi:10.1001/ archderm.1971.04000180001001

11. Igarashi R. [An immunohistochemical study of IgE in the skin of patients with systemic lupus erythematosus (author's transl)]. Nihon Hifuka Gakkai Zasshi (1975) 85(7):385-93.

12. Goldman JA, Klimek GA, Ali R. Allergy in systemic lupus erythematosus. IgE levels and reaginic phenomenon. Arthritis Rheum (1976) 19(4):669-76. ART1780190403>3.0.CO;2-E

13. Altrichter S, Peter HJ, Pisarevskaja D, Metz M, Martus P, Maurer M. IgE mediated autoallergy against thyroid peroxidase - a novel pathomechanism of chronic spontaneous urticaria? PLoS One (2011) 6(4):e14794. doi:10.1371/ journal.pone.0014794

\section{Unanswered Questions?}

Many questions on IgE autoantibodies remain unanswered.

- Is IgE to self different from IgE to exogenous antigens in terms of its biochemical properties, its glycosylation, or its folding?

- Where is auto-IgE produced and what B cells are involved?

- Does the auto-IgE come from CD5+ B1 B cells of the marginal zone of the spleen (poorly negatively selected B cells that often produce autoantibodies) or from B cells that were previously allergen or pathogen reactive?

- Does the production of auto-IgE precede the onset of autoallergic signs and symptoms and when and why does it stop?

These and other questions are currently addressed by ongoing research. The answers that will come from these and future studies will help to better understand the biology and relevance of $\operatorname{IgE}$ autoantibodies in disease and to develop better approaches for the prevention and treatment of autoallergies.

\section{AUTHOR CONTRIBUTIONS}

All authors listed have made a substantial, direct, and intellectual contribution to the work and approved it for publication.

14. Chang TW, Chen C, Lin CJ, Metz M, Church MK, Maurer M. The potential pharmacologic mechanisms of omalizumab in patients with chronic spontaneous urticaria. J Allergy Clin Immunol (2015) 135(2):337-42. doi:10.1016/j. jaci.2014.04.036

15. Metz M, Ohanyan T, Church MK, Maurer M. Omalizumab is an effective and rapidly acting therapy in difficult-to-treat chronic urticaria: a retrospective clinical analysis. J Dermatol Sci (2014) 73(1):57-62. doi:10.1016/j. jdermsci.2013.08.011

16. Valenta R, Duchene M, Pettenburger K, Sillaber C, Valent P, Bettelheim P, et al. Identification of profilin as a novel pollen allergen; IgE autoreactivity in sensitized individuals. Science (1991) 253(5019):557-60. doi:10.1126/ science. 1857985

17. Garn H, Mittermann I, Valenta R, Renz H. Autosensitization as a pathomechanism in asthma. Ann N Y Acad Sci (2007) 1107:417-25. doi:10.1196/ annals.1381.044

18. Tedeschi A, Asero R. Asthma and autoimmunity: a complex but intriguing relation. Expert Rev Clin Immunol (2008) 4(6):767-76. doi:10.1586/17446 66X.4.6.767

19. Tang TS, Bieber T, Williams HC. Does “autoreactivity" play a role in atopic dermatitis? J Allergy Clin Immunol (2012) 129(5):1209-15.e2. doi:10.1016/j. jaci.2012.02.002

20. Valenta R, Seiberler S, Natter S, Mahler V, Mossabeb R, Ring J, et al. Autoallergy: a pathogenetic factor in atopic dermatitis? J Allergy Clin Immunol (2000) 105(3):432-7. doi:10.1067/mai.2000.104783

21. Zhang L, Guo L, Huang Y, Wang T, Shi X, Chang H, et al. Allergic diseases, immunoglobulin E, and autoimmune pancreatitis: a retrospective study of 22 patients. Chin Med J (Engl) (2014) 127(23):4104-9.

22. van Beek N, Schulze FS, Zillikens D, Schmidt E. IgE-mediated mechanisms in bullous pemphigoid and other autoimmune bullous diseases. Expert Rev Clin Immunol (2016) 12(3):267-77. doi:10.1586/1744666X.2016.1123092

23. PanaszekB, Pawlowicz R, Grzegrzolka J, Obojski A. Autoreactive IgE in chronic spontaneous/idiopathic urticaria and basophil/mastocyte priming phenomenon, as a feature of autoimmune nature of the syndrome. Arch Immunol Ther Exp (Warsz) (2017) 65(2):137-43. doi:10.1007/s00005-016-0417-7

24. Guo J, Rapoport B, McLachlan SM. Thyroid peroxidase autoantibodies of IgE class in thyroid autoimmunity. Clin Immunol Immunopathol (1997) 82(2):157-62. doi:10.1006/clin.1996.4297 
25. Elisei R, Weightman D, Kendall-Taylor P, Vassart G, Ludgate M. Muscle autoantigens in thyroid associated ophthalmopathy: the limits of molecular genetics. J Endocrinol Invest (1993) 16(7):533-40. doi:10.1007/BF03348900

26. Mikol DD, Ditlow C, Usatin D, Biswas P, Kalbfleisch J, Milner A, et al. Serum IgE reactive against small myelin protein-derived peptides is increased in multiple sclerosis patients. JNeuroimmunol (2006) 180(1-2):40-9. doi:10.1016/j.jneuroim.2006.06.030

27. Permin H, Wiik A. The prevalence of IgE antinuclear antibodies in rheumatoid arthritis and systemic lupus erythematosus. Acta Pathol Microbiol Scand C (1978) 86C(5):245-9.

28. Sanjuan MA, Sagar D, Kolbeck R. Role of IgE in autoimmunity. J Allergy Clin Immunol (2016) 137(6):1651-61. doi:10.1016/j.jaci.2016.04.007

29. Muino JC, Juarez CP, Luna JD, Castro CC, Wolff EG, Ferrero M, et al. The importance of specific IgG and IgE autoantibodies to retinal S antigen, total serum IgE, and sCD23 levels in autoimmune and infectious uveitis. J Clin Immunol (1999) 19(4):215-22. doi:10.1023/A:1020516029883

30. Keller P. Beitrag zu den beziehungen von asthma und ekzem. Arch Derm Syph Berl (1924) 148:82-91. doi:10.1007/BF01827500

31. Storm van Leeuwen W, Bien Z, Varekamp H. Über die hautreaktion mit extrakten menschlicher kopfhautschuppen bei allergischen krankheiten. Klin Wochenschr (1926) 5:1023-5. doi:10.1007/BF01717944

32. Hampton SF, Cooke RA. The sensitivity of man to human dander, with particular reference to eczema (allergic dermatitis). J Allergy (1941) 13:63-76. doi:10.1016/S0021-8707(41)90008-4

33. Simon FA. Human dander: an important cause of infantile eczema. JAMA (1944) 125:350-9. doi:10.1001/jama.1944.02850230030008

34. Simon FA. On the allergen in human dander. J Allergy (1944) 15:338-45. doi:10.1016/S0021-8707(44)90143-7

35. Simon FA. The allergen of human dander present in skin of the general body surface. J Invest Dermatol (1947) 9(6):329-32. doi:10.1038/jid.1947.106

36. Valenta R, Maurer D, Steiner R, Seiberler S, Sperr WR, Valent P, et al. Immunoglobulin $\mathrm{E}$ response to human proteins in atopic patients. J Invest Dermatol (1996) 107(2):203-8. doi:10.1111/1523-1747.ep12329617

37. Szakos E, Lakos G, Aleksza M, Gyimesi E, Pall G, Fodor B, et al. Association between the occurrence of the anticardiolipin IgM and mite allergen-specific IgE antibodies in children with extrinsic type of atopic eczema/dermatitis syndrome. Allergy (2004) 59(2):164-7. doi:10.1046/j.1398-9995.2003.00367.x

38. Schmid-Grendelmeier P, Fluckiger S, Disch R, Trautmann A, Wuthrich B, Blaser $\mathrm{K}$, et al. IgE-mediated and $\mathrm{T}$ cell-mediated autoimmunity against manganese superoxide dismutase in atopic dermatitis. J Allergy Clin Immunol (2005) 115(5):1068-75. doi:10.1016/j.jaci.2005.01.065

39. Higashi N, Niimi Y, Aoki M, Kawana S. Clinical features of antinuclear antibody-positive patients with atopic dermatitis. J Nippon Med Sch (2009) 76(6):300-7. doi:10.1272/jnms.76.300

40. Altrichter S, Kriehuber E, Moser J, Valenta R, Kopp T, Stingl G. Serum IgE autoantibodies target keratinocytes in patients with atopic dermatitis. J Invest Dermatol (2008) 128(9):2232-9. doi:10.1038/jid.2008.80

41. Zeller S, Rhyner C, Meyer N, Schmid-Grendelmeier P, Akdis CA, Crameri R. Exploring the repertoire of IgE-binding self-antigens associated with atopic eczema. J Allergy Clin Immunol (2009) 124(2): 278-85, 285.e1-7. doi:10.1016/j.jaci.2009.05.015

42. Balaji H, Heratizadeh A, Wichmann K, Niebuhr M, Crameri R, Scheynius A, et al. Malassezia sympodialis thioredoxin-specific T cells are highly cross-reactive to human thioredoxin in atopic dermatitis. J Allergy Clin Immunol (2011) 128(1):92-9.e4. doi:10.1016/j.jaci.2011.02.043

43. Watanabe K, Muro Y, Sugiura K, Tomita Y. IgE and IgG(4) autoantibodies against DFS70/LEDGF in atopic dermatitis. Autoimmunity (2011) 44(6):511-9. doi:10.3109/08916934.2010.549157

44. Natter S, Seiberler S, Hufnagl P, Binder BR, Hirschl AM, Ring J, et al. Isolation of cDNA clones coding for IgE autoantigens with serum IgE from atopic dermatitis patients. FASEB J (1998) 12(14):1559-69. doi:10.1096/ fasebj.12.14.1559

45. Valenta R, Natter S, Seiberler S, Wichlas S, Maurer D, Hess M, et al. Molecular characterization of an autoallergen, Hom s 1, identified by serum $\operatorname{IgE}$ from atopic dermatitis patients. J Invest Dermatol (1998) 111(6):1178-83. doi:10.1046/j.1523-1747.1998.00413.x

46. Mothes N, Niggemann B, Jenneck C, Hagemann T, Weidinger S, Bieber T, et al. The cradle of IgE autoreactivity in atopic eczema lies in early infancy. J Allergy Clin Immunol (2005) 116(3):706-9. doi:10.1016/j.jaci.2005.06.025
47. Zhu H, Luo H, Yan M, Zuo X, Li QZ. Autoantigen microarray for high-throughput autoantibody profiling in systemic lupus erythematosus. Genomics Proteomics Bioinformatics (2015) 13(4):210-8. doi:10.1016/j. gpb.2015.09.001

48. Atta AM, Santiago MB, Guerra FG, Pereira MM, Sousa Atta ML. Autoimmune response of IgE antibodies to cellular self-antigens in systemic lupus erythematosus. Int Arch Allergy Immunol (2010) 152(4):401-6. doi:10.1159/000288293

49. Dema B, Pellefigues C, Hasni S, Gault N, Jiang C, Ricks TK, et al. Autoreactive $\operatorname{IgE}$ is prevalent in systemic lupus erythematosus and is associated with increased disease activity and nephritis. PLoS One (2014) 9(2):e90424. doi:10.1371/journal.pone.0090424

50. Hanaoka H, Okazaki Y, Satoh T, Kaneko Y, Yasuoka H, Seta N, et al. Circulating anti-double-stranded DNA antibody-secreting cells in patients with systemic lupus erythematosus: a novel biomarker for disease activity. Lupus (2012) 21(12):1284-93. doi:10.1177/0961203312453191

51. Rhyner C, Daigle I, Crameri R. Auto-reactive IgE responses to acidic ribosomal $\mathrm{P}(2)$ protein in systemic lupus erythematosus. Allergy (2011) 66(8):1127-9. doi:10.1111/j.1398-9995.2011.02581.x

52. Sekigawa I, Seta N, Yamada M, Iida N, Hashimoto H, Ogawa H. Possible importance of immunoglobulin $\mathrm{E}$ in foetal loss by mothers with anti-SSA antibody. Scand J Rheumatol (2004) 33(1):44-6. doi:10.1080/03009740310004658

53. Brucato A, Cimaz R, Caporali R, Ramoni V, Buyon J. Pregnancy outcomes in patients with autoimmune diseases and anti-Ro/SSA antibodies. Clin Rev Allergy Immunol (2011) 40(1):27-41. doi:10.1007/s12016-009-8190-6

54. Christophoridis S, Budinger L, Borradori L, Hunziker T, Merk HF, Hertl M. IgG, IgA and IgE autoantibodies against the ectodomain of BP180 in patients with bullous and cicatricial pemphigoid and linear IgA bullous dermatosis. Br J Dermatol (2000) 143(2):349-55. doi:10.1046/j.1365-2133.2000. 03661.x

55. Thoma-Uszynski S, Uter W, Schwietzke S, Hofmann SC, Hunziker T, Bernard P, et al. BP230- and BP180-specific auto-antibodies in bullous pemphigoid. J Invest Dermatol (2004) 122(6):1413-22. doi:10.1111/j.0022-202X.2004.22603.x

56. van Beek N, Luttmann N, Huebner F, Recke A, Karl I, Schulze FS, et al. Correlation of serum levels of IgE autoantibodies against BP180 with bullous pemphigoid disease activity. JAMA Dermatol (2017) 153(1):30-8. doi:10.1001/jamadermatol.2016.3357

57. Hofmann S, Thoma-Uszynski S, Hunziker T, Bernard P, Koebnick C, Stauber A, et al. Severity and phenotype of bullous pemphigoid relate to autoantibody profile against the $\mathrm{NH} 2$ - and $\mathrm{COOH}$-terminal regions of the BP180 ectodomain. J Invest Dermatol (2002) 119(5):1065-73. doi:10.1046/j.1523-1747.2002.19529.x

58. Dresow SK, Sitaru C, Recke A, Oostingh GJ, Zillikens D, Gibbs BF. IgE autoantibodies against the intracellular domain of BP180. Br J Dermatol (2009) 160(2):429-32. doi:10.1111/j.1365-2133.2008.08858.x

59. Dimson OG, Giudice GJ, Fu CL, Van den Bergh F, Warren SJ, Janson MM, et al. Identification of a potential effector function for $\operatorname{IgE}$ autoantibodies in the organ-specific autoimmune disease bullous pemphigoid. JInvest Dermatol (2003) 120(5):784-8. doi:10.1046/j.1523-1747.2003.12146.X

60. Iwata Y, Komura K, Kodera M, Usuda T, Yokoyama Y, Hara T, et al. Correlation of IgE autoantibody to BP180 with a severe form of bullous pemphigoid. Arch Dermatol (2008) 144(1):41-8. doi:10.1001/archdermatol.2007.9

61. Ishiura N, Fujimoto M, Watanabe R, Nakashima H, Kuwano Y, Yazawa $\mathrm{N}$, et al. Serum levels of IgE anti-BP180 and anti-BP230 autoantibodies in patients with bullous pemphigoid. J Dermatol Sci (2008) 49(2):153-61. doi:10.1016/j.jdermsci.2007.08.008

62. Yayli S, Pelivani N, Beltraminelli H, Wirthmuller U, Beleznay Z, Horn M, et al. Detection of linear IgE deposits in bullous pemphigoid and mucous membrane pemphigoid: a useful clue for diagnosis. Br J Dermatol (2011) 165(5):1133-7. doi:10.1111/j.1365-2133.2011.10481.x

63. Dopp R, Schmidt E, Chimanovitch I, Leverkus M, Brocker EB, Zillikens D. IgG4 and IgE are the major immunoglobulins targeting the NC16A domain of BP180 in bullous pemphigoid: serum levels of these immunoglobulins reflect disease activity. J Am Acad Dermatol (2000) 42(4):577-83. doi:10.1067/mjd.2000.103986

64. Pomponi D, Di Zenzo G, Zennaro D, Calabresi V, Eming R, Zuzzi S, et al. Detection of IgG and IgE reactivity to BP180 using the ISAC(R) microarray system. Br J Dermatol (2013) 168(6):1205-14. doi:10.1111/bjd.12161 
65. Liu B, Zuo YG, Zhou XP, He CX, Li J, Tie D, et al. [Establishment of enzymelinked immunosorbent assay in the detection of BP180NC16A-specific IgE and its significance in bullous pemphigoid]. Zhonghua Yi Xue Za Zhi (2013) 93(28):2244-7.

66. Messingham KA, Noe MH, Chapman MA, Giudice GJ, Fairley JA. A novel ELISA reveals high frequencies of BP180-specific IgE production in bullous pemphigoid. J Immunol Methods (2009) 346(1-2):18-25. doi:10.1016/j. jim.2009.04.013

67. Engineer L, Bhol K, Kumari S, Razzaque Ahmed A. Bullous pemphigoid: interaction of interleukin 5, anti-basement membrane zone antibodies and eosinophils. A preliminary observation. Cytokine (2001) 13(1):32-8. doi:10.1006/cyto.2000.0791

68. Fania L, Caldarola G, Muller R, Brandt O, Pellicano R, Feliciani C, et al. IgE recognition of bullous pemphigoid (BP) 180 and BP230 in BP patients and elderly individuals with pruritic dermatoses. Clin Immunol (2012) 143(3):236-45. doi:10.1016/j.clim.2012.02.003

69. Cozzani E, Micalizzi C, Parodi A, Rebora A. Anti-230 kDa circulating IgE in bullous pemphigoid: relationship with disease activity. Acta Derm Venereol (1997) $77(3): 236$.

70. Ghohestani RF, Cozzani E, Delaporte E, Nicolas JF, Parodi A, Claudy A. IgE antibodies in sera from patients with bullous pemphigoid are autoantibodies preferentially directed against the $230-\mathrm{kDa}$ epidermal antigen (BP230). J Clin Immunol (1998) 18(3):202-9. doi:10.1023/A:1020531005776

71. Bruns GR, Ablin RJ, Guinan PD. Serum immunoglobulin E in pemphigus. J Invest Dermatol (1978) 71(3):217-8. doi:10.1111/1523-1747.ep12547283

72. Nagel A, Lang A, Engel D, Podstawa E, Hunzelmann N, de Pita O, et al. Clinical activity of pemphigus vulgaris relates to $\operatorname{IgE}$ autoantibodies against desmoglein 3. Clin Immunol (2010) 134(3):320-30. doi:10.1016/j. clim.2009.11.006

73. Spaeth S, Riechers R, Borradori L, Zillikens D, Budinger L, Hertl M. IgG, IgA and IgE autoantibodies against the ectodomain of desmoglein 3 in active pemphigus vulgaris. $B r$ J Dermatol (2001) 144(6):1183-8. doi:10.1046/j.1365-2133.2001.04228.x

74. Natsuga K, Nishie W, Shinkuma S, Moriuchi R, Shibata M, Nishimura $\mathrm{M}$, et al. Circulating IgA and IgE autoantibodies in antilaminin-332 mucous membrane pemphigoid. Br J Dermatol (2010) 162(3):513-7. doi:10.1111/j.1365-2133.2009.09508.x

75. Qian Y, Prisayanh P, Andraca E, Qaqish BF, Aoki V, Hans-Filhio G, et al. IgE, IgM, and IgG4 anti-desmoglein 1 autoantibody profile in endemic pemphigus foliaceus (fogo selvagem). J Invest Dermatol (2011) 131(4):985-7. doi:10.1038/jid.2010.403

76. Qian Y, Jeong JS, Abdeladhim M, Valenzuela JG, Aoki V, Hans-Filhio G, et al. IgE anti-LJM11 sand fly salivary antigen may herald the onset of fogo selvagem in endemic Brazilian regions. J Invest Dermatol (2015) 135(3):913-5. doi:10.1038/jid.2014.430

77. Maurer M, Metz M, Magerl M, Siebenhaar F, Staubach P. [Autoreactive urticaria and autoimmune urticaria]. Hautarzt (2004) 55(4):350-6. doi:10.1007/ s00105-004-0692-9

78. Maurer M, Rosen K, Hsieh HJ, Saini S, Grattan C, Gimenez-Arnau A, et al. Omalizumab for the treatment of chronic idiopathic or spontaneous urticaria. NEngl J Med (2013) 368(10):924-35. doi:10.1056/NEJMoa1215372

79. Caliskaner Z, Ozturk S, Turan M, Karaayvaz M. Skin test positivity to aeroallergens in the patients with chronic urticaria without allergic respiratory disease. J Investig Allergol Clin Immunol (2004) 14(1):50-4.

80. Kulthanan K, Jiamton S, Rutnin NO, Insawang M, Pinkaew S. Prevalence and relevance of the positivity of skin prick testing in patients with chronic urticaria. J Dermatol (2008) 35(6):330-5. doi:10.1111/j.1346-8138.2008. 00477.x

81. Gecer E, Erdem T. Aeroallergen prick skin test and autologous serum skin test results in patients with chronic urticaria and their comparison. Ann Dermatol (2012) 24(4):472-4. doi:10.5021/ad.2012.24.4.472

82. Song Z, Zhai Z, Zhong H, Zhou Z, Chen W, Hao F. Evaluation of autologous serum skin test and skin prick test reactivity to house dust mite in patients with chronic spontaneous urticaria. PLoS One (2013) 8(5):e64142. doi:10.1371/journal.pone.0064142

83. Staubach P, Vonend A, Burow G, Metz M, Magerl M, Maurer M. Patients with chronic urticaria exhibit increased rates of sensitisation to Candida albicans, but not to common moulds. Mycoses (2009) 52(4):334-8. doi:10.1111/j.1439-0507.2008.01601.x
84. Zhang M, Liu F, Liu H, Shen Y, Kong Q, Sang H. Sensitization and cross-reactions of dermatophyte and Candida albicans allergens in patients with chronic urticaria. Int J Dermatol (2016) 55(10):1138-42. doi:10.1111/ijd.13162

85. Kulthanan K, Wachirakaphan C. Prevalence and clinical characteristics of chronic urticaria and positive skin prick testing to mites. Acta Derm Venereol (2008) 88(6):584-8. doi:10.2340/00015555-0546

86. Zuberbier T, Balke M, Worm M, Edenharter G, Maurer M. Epidemiology of urticaria: a representative cross-sectional population survey. Clin Exp Dermatol (2010) 35(8):869-73. doi:10.1111/j.1365-2230.2010.03840.x

87. Augey F, Gunera-Saad N, Bensaid B, Nosbaum A, Berard F, Nicolas JF. Chronic spontaneous urticaria is not an allergic disease. Eur J Dermatol (2011) 21(3):349-53. doi:10.1684/ejd.2011.1285

88. Kolkhir P, Metz M, Altrichter S, Maurer M. Comorbidity of chronic spontaneous urticaria and autoimmune thyroid diseases: a systematic review. Allergy (2017) 72(10):1440-60. doi:10.1111/all.13182

89. Bar-Sela S, Reshef T, Mekori YA. IgE antithyroid microsomal antibodies in a patient with chronic urticaria. J Allergy Clin Immunol (1999) 103(6):1216-7. doi:10.1016/S0091-6749(99)70204-6

90. Atta AM, Rodrigues MZ, Sousa CP, Medeiros Junior M, Sousa-Atta ML. Autoantibody production in chronic idiopathic urticaria is not associated with Helicobacter pylori infection. Braz J Med Biol Res (2004) 37(1):13-7. doi:10.1590/S0100-879X2004000100002

91. Concha LB, Chang CC, Szema AM, Dattwyler RJ, Carlson HE. IgE antithyroid antibodies in patients with Hashimoto's disease and chronic urticaria. Allergy Asthma Proc (2004) 25(5):293-6.

92. Tedeschi A, Lorini M, Asero R. Anti-thyroid peroxidase IgE in patients with chronic urticaria. J Allergy Clin Immunol (2001) 108(3):467-8. doi:10.1067/ mai.2001.117792

93. Kadooka Y, Idota T, Gunji H, Shimatani M, Kawakami H, Dosako S, et al. A method for measuring specific IgE in sera by direct ELISA without interference by IgG competition or IgG autoantibodies to IgE. Int Arch Allergy Immunol (2000) 122(4):264-9. doi:10.1159/000024408

94. Shin YS, Suh DH, Yang EM, Ye YM, Park HS. Serum specific IgE to thyroid peroxidase activates basophils in aspirin intolerant urticaria. J Korean Med Sci (2015) 30(6):705-9. doi:10.3346/jkms.2015.30.6.705

95. Kolkhir P, Borzova E, Grattan C, Asero R, Pogorelov D, Maurer M. Autoimmune comorbidity in chronic spontaneous urticaria: a systematic review. Autoimmun Rev (2017) 16(12):1196-208. doi:10.1016/j. autrev.2017.10.003

96. Kolkhir P, Pogorelov D, Olisova O, Maurer M. Comorbidity and pathogenic links of chronic spontaneous urticaria and systemic lupus erythematosus - a systematic review. Clin Exp Allergy (2016) 46(2):275-87. doi:10.1111/ cea. 12673

97. Hatada Y, Kashiwakura J, Hayama K, Fujisawa D, Sasaki-Sakamoto T, Terui T, et al. Significantly high levels of anti-dsDNA immunoglobulin E in sera and the ability of dsDNA to induce the degranulation of basophils from chronic urticaria patients. Int Arch Allergy Immunol (2013) 161(Suppl 2):154-8. doi: $10.1159 / 000350388$

98. Schmetzer O, Lakin E, Topal FA, Preusse P, Freier D, Church MK, et al. IL-24 is a common and specific autoantigen of IgE in patients with chronic spontaneous urticaria. J Allergy Clin Immunol (2017). doi:10.1016/j.jaci.2017.10.035

99. Romero MD, Muino JC, Bianco GA, Ferrero M, Juarez CP, Luna JD, et al. Circulating anti-galectin-1 antibodies are associated with the severity of ocular disease in autoimmune and infectious uveitis. Invest Ophthalmol Vis Sci (2006) 47(4):1550-6. doi:10.1167/iovs.05-1234

100. Meretey K, Falus A, Erhardt CC, Maini RN. IgE and IgE-rheumatoid factors in circulating immune complexes in rheumatoid arthritis. Ann Rheum Dis (1982) 41(4):405-8. doi:10.1136/ard.41.4.405

101. Schuerwegh AJ, Ioan-Facsinay A, Dorjee AL, Roos J, Bajema IM, van der Voort EI, et al. Evidence for a functional role of IgE anticitrullinated protein antibodies in rheumatoid arthritis. Proc Natl Acad Sci U S A (2010) 107(6):2586-91. doi:10.1073/pnas.0913054107

102. Schuerwegh AJ, Ioan-Facsinay A, Dorjee AL, Roos J, Bajema IM, van der Voort EI, et al. Retraction for Schuerwegh et al., evidence for a functional role of IgE anticitrullinated protein antibodies in rheumatoid arthritis. Proc Natl Acad Sci U S A (2013) 110(50):20345. doi:10.1073/pnas.1320459110

103. Monteiro L, Souza-Machado A, Menezes C, Melo A. Association between allergies and multiple sclerosis: a systematic review and meta-analysis. Acta Neurol Scand (2011) 123(1):1-7. doi:10.1111/j.1600-0404.2010.01355.x 
104. Matsui Y, Heiner DC, Beall GN. IgE and IgE autoantibodies in patients with autoimmune thyroid disorders and their relatives. Proc Soc Exp Biol Med (1978) 158(1):73-6. doi:10.3181/00379727-158-40142

105. Inoue M, Rakugi H, Nakamaru M, Masugi F, Ogihara T, Takai S. [Graves' disease with markedly elevated serum immunoglobulin E]. Nihon Naibunpi Gakkai Zasshi (1989) 65(11):1264-9.

106. Sayinalp S, Akalin S, Sayinalp N, Erbas T, Bayraktar M, Ozcebe OI, et al. Serum immunoglobulin E and soluble CD23 in patients with Graves' disease. Horm Metab Res (1996) 28(3):133-7. doi:10.1055/s-2007-979145

107. Sato A, Takemura Y, Yamada T, Ohtsuka H, Sakai H, Miyahara Y, et al. A possible role of immunoglobulin $\mathrm{E}$ in patients with hyperthyroid Graves' disease. J Clin Endocrinol Metab (1999) 84(10):3602-5. doi:10.1210/jcem.84.10.6038

108. Yamada T, Sato A, Komiya I, Nishimori T, Ito Y, Terao A, et al. An elevation of serum immunoglobulin E provides a new aspect of hyperthyroid Graves' disease. J Clin Endocrinol Metab (2000) 85(8):2775-8. doi:10.1210/ jcem.85.8.6741

109. Latifi-Pupovci H, Gacaferri-Lumezi B, Lokaj-Berisha V. There is no elevation of immunoglobulin e levels in Albanian patients with autoimmune thyroid diseases. J Thyroid Res (2014) 2014:283709. doi:10.1155/2014/283709

110. Raikow RB, Dalbow MH, Kennerdell JS, Compher K, Machen L, Hiller W, et al. Immunohistochemical evidence for IgE involvement in Graves' orbitopathy. Ophthalmology (1990) 97(5):629-35. doi:10.1016/S0161-6420(90)32548-4

111. Raikow RB, Tyutyunikov A, Kennerdell JS, Kazim M, Dalbow MH, Scalise D. Correlation of serum immunoglobulin E elevations with clinical stages of dysthyroid orbitopathy. Ophthalmology (1992) 99(3):361-5. doi:10.1016/ S0161-6420(92)31964-5

112. Hirano K, Tada M, Isayama H, Kawakubo K, Yagioka H, Sasaki T, et al. Clinical analysis of high serum IgE in autoimmune pancreatitis. World J Gastroenterol (2010) 16(41):5241-6. doi:10.3748/wjg.v16.i41.5241

113. van Toorenenbergen AW, van Heerde MJ, van Buuren HR. Potential value of serum total IgE for differentiation between autoimmune pancreatitis and pancreatic cancer. Scand JImmunol (2010) 72(5):444-8. doi:10.1111/j.1365-3083.2010.02453.x

114. Bunder R, Mittermann I, Herz U, Focke M, Wegmann M, Valenta R, et al. Induction of autoallergy with an environmental allergen mimicking a self protein in a murine model of experimental allergic asthma. J Allergy Clin Immunol (2004) 114(2):422-8. doi:10.1016/j.jaci.2004.05.029

115. Lassalle $\mathrm{P}$, Joseph $\mathrm{M}$, Ramon $\mathrm{P}$, Dracon $\mathrm{M}$, Tonnel AB, Capron A. Plasmapheresis in a patient with severe asthma associated with auto-antibodies to platelets. Clin Exp Allergy (1990) 20(6):707-12. doi:10.111 $1 / \mathrm{j} .1365-2222.1990 . t b 02712 . x$

116. Mayer C, Appenzeller U, Seelbach H, Achatz G, Oberkofler H, Breitenbach $\mathrm{M}$, et al. Humoral and cell-mediated autoimmune reactions to human acidic ribosomal P2 protein in individuals sensitized to Aspergillus fumigatus P2 protein. J Exp Med (1999) 189(9):1507-12. doi:10.1084/jem.189.9.1507

117. De Schryver E, Calus L, Bonte H, Natalie R, Gould H, Donovan E, et al. The quest for autoreactive antibodies in nasal polyps. J Allergy Clin Immunol (2016) 138(3):893-895.e5. doi:10.1016/j.jaci.2016.03.040

118. Cooper GS, Bynum ML, Somers EC. Recent insights in the epidemiology of autoimmune diseases: improved prevalence estimates and understanding of clustering of diseases. J Autoimmun (2009) 33(3-4):197-207. doi:10.1016/j. jaut.2009.09.008

119. Panda S, Ding JL. Natural antibodies bridge innate and adaptive immunity. J Immunol (2015) 194(1):13-20. doi:10.4049/jimmunol.1400844

120. Kapsogeorgou EK, Tzioufas AG. Autoantibodies in autoimmune diseases: clinical and Critical evaluation. Isr Med Assoc J (2016) 18(9):519-24.

121. Fu SL, Pierre J, Smith-Norowitz TA, Hagler M, Bowne W, Pincus MR, et al. Immunoglobulin $\mathrm{E}$ antibodies from pancreatic cancer patients mediate antibody-dependentcell-mediated cytotoxicityagainstpancreaticcancercells.Clin Exp Immunol (2008) 153(3):401-9. doi:10.1111/j.1365-2249.2008.03726.x

122. Das MK, Mishra A, Beuria MK, Dash AP. Human natural antibodies to Culex quinquefasciatus: age-dependent occurrence. J Am Mosq Control Assoc (1991) 7(2):319-21.

123. Lorenzo S, Iglesias R, Paniagua E, Ansotegui I, Alonso JM, Ubeira FM. Natural antibodies to nematode biotinyl-enzymes in human sera. Med Microbiol Immunol (2001) 189(4):177-83. doi:10.1007/s004300100065

124. Otsuka A, Nomura T, Rerknimitr P, Seidel JA, Honda T, Kabashima K. The interplay between genetic and environmental factors in the pathogenesis of atopic dermatitis. Immunol Rev (2017) 278(1):246-62. doi:10.1111/imr.12545
125. Cipriani F, Ricci G, Leoni MC, Capra L, Baviera G, Longo G, et al. Autoimmunity in atopic dermatitis: biomarker or simply epiphenomenon? J Dermatol (2014) 41(7):569-76. doi:10.1111/1346-8138.12464

126. Hradetzky S, Werfel T, Rosner LM. Autoallergy in atopic dermatitis. Allergo $J$ Int (2015) 24(1):16-22. doi:10.1007/s40629-015-0037-5

127. Wang HH, Li YC, Huang YC. Efficacy of omalizumab in patients with atopic dermatitis: a systematic review and meta-analysis. J Allergy Clin Immunol (2016) 138(6):1719-22.e1. doi:10.1016/j.jaci.2016.05.038

128. Holm JG, Agner T, Sand C, Thomsen SF. Omalizumab for atopic dermatitis: case series and a systematic review of the literature. Int J Dermatol (2017) 56(1):18-26. doi:10.1111/ijd.13353

129. Henault J, Riggs JM, Karnell JL, Liarski VM, Li J, Shirinian L, et al. Selfreactive $\operatorname{IgE}$ exacerbates interferon responses associated with autoimmunity. Nat Immunol (2016) 17(2):196-203. doi:10.1038/ni.3326

130. Ettinger R, Karnell JL, Henault J, Panda SK, Riggs JM, Kolbeck R, et al. Pathogenic mechanisms of IgE-mediated inflammation in self-destructive autoimmune responses. Autoimmunity (2017) 50(1):25-36. doi:10.1080/08 916934.2017.1280670

131. Pan Q, Gong L, Xiao H, Feng Y, Li L, Deng Z, et al. Basophil activation-dependent autoantibody and interleukin-17 production exacerbate systemic lupus erythematosus. Front Immunol (2017) 8:348. doi:10.3389/fimmu.2017.00348

132. Freire PC, Munoz CH, Stingl G. IgE autoreactivity in bullous pemphigoid: eosinophils and mast cells as major targets of pathogenic immune reactants. Br J Dermatol (2017) 177(6):1644-53. doi:10.1111/bjd.15924

133. Fairley JA, Baum CL, Brandt DS, Messingham KA. Pathogenicity of IgE in autoimmunity: successful treatment of bullous pemphigoid with omalizumab. J Allergy Clin Immunol (2009) 123(3):704-5. doi:10.1016/j.jaci.2008.11.035

134. Dufour C, Souillet AL, Chaneliere C, Jouen F, Bodemer C, Jullien D, et al. Successfulmanagement of severeinfantbullouspemphigoid with omalizumab. Br J Dermatol (2012) 166(5):1140-2. doi:10.1111/j.1365-2133.2011.10748.x

135. London VA, Kim GH, Fairley JA, Woodley DT. Successful treatment of bullous pemphigoid with omalizumab. Arch Dermatol (2012) 148(11):1241-3. doi:10.1001/archdermatol.2012.1604

136. Yalcin AD, Genc GE, Celik B, Gumuslu S. Anti-IgE monoclonal antibody (omalizumab) is effective in treating bullous pemphigoid and its effects on soluble CD200. Clin Lab (2014) 60(3):523-4. doi:10.7754/Clin.Lab.2013.130642

137. Yu KK, Crew AB, Messingham KA, Fairley JA, Woodley DT. Omalizumab therapy for bullous pemphigoid. J Am Acad Dermatol (2014) 71(3):468-74. doi:10.1016/j.jaad.2014.04.053

138. Balakirski G, Alkhateeb A, Merk HF, Leverkus M, Megahed M. Successful treatment of bullous pemphigoid with omalizumab as corticosteroid-sparing agent: report of two cases and review of literature. J Eur Acad Dermatol Venereol (2016) 30(10):1778-82. doi:10.1111/jdv.13758

139. Gonul MZ, Keseroglu HO, Ergin C, Ozcan I, Erdem O. Bullous pemphigoid successfully treated with omalizumab. Indian J Dermatol Venereol Leprol (2016) 82(5):577-9. doi:10.4103/0378-6323.183628

140. Menzinger S, Kaya G, Schmidt E, Fontao L, Laffitte E. Biological and clinical response to omalizumab in a patient with bullous pemphigoid. Acta Derm Venereol (2017) 98(2):284-6. doi:10.2340/00015555-2845

141. Kolkhir P, Church MK, Weller K, Metz M, Schmetzer O, Maurer M. Autoimmune chronic spontaneous urticaria: what we know and what we do not know. J Allergy Clin Immunol (2017) 139(6):1772-81.e1. doi:10.1016/j. jaci.2016.08.050

142. Metz M, Maurer M. Omalizumab in chronic urticaria. Curr Opin Allergy Clin Immunol (2012) 12(4):406-11. doi:10.1097/ACI.0b013e328355365a

143. Urgert MC, van den Elzen MT, Knulst AC, Fedorowicz Z, van Zuuren EJ. Omalizumab in patients with chronic spontaneous urticaria: a systematic review and GRADE assessment. Br J Dermatol (2015) 173(2):404-15. doi:10.1111/bjd.13845

144. Zhao ZT, Ji CM, Yu WJ, Meng L, Hawro T, Wei JF, et al. Omalizumab for the treatment of chronic spontaneous urticaria: a meta-analysis of randomized clinical trials. J Allergy Clin Immunol (2016) 137(6):1742-50.e4. doi:10.1016/j.jaci.2015.12.1342

145. Maurer M, Metz M, Brehler R, Hillen U, Jakob T, Mahler V, et al. Omalizumab treatment in patients with chronic inducible urticaria: a systematic review of published evidence. JAllergy Clin Immunol (2017) 141(2):638-49. doi:10.1016/j.jaci.2017.06.032

146. Maurer M, Altrichter S, Bieber T, Biedermann T, Brautigam M, Seyfried S, et al. Efficacy and safety of omalizumab in patients with chronic urticaria 
who exhibit IgE against thyroperoxidase. JAllergy Clin Immunol (2011) 128(1):202-9.e5. doi:10.1016/j.jaci.2011.04.038

147. Gericke J, Metz M, Ohanyan T, Weller K, Altrichter S, Skov PS, et al. Serum autoreactivity predicts time to response to omalizumab therapy in chronic spontaneous urticaria. J Allergy Clin Immunol (2017) 139(3):1059-61.e1. doi:10.1016/j.jaci.2016.07.047

148. Houser DD, Arbesman CE, Ito K, Wicher K. Cold urticaria. Immunologic studies. Am J Med (1970) 49(1):23-33.

149. Kaplan AP, Garofalo J, Sigler R, Hauber T. Idiopathic cold urticaria: in vitro demonstration of histamine release upon challenge of skin biopsies. $N$ Engl J Med (1981) 305(18):1074-7. doi:10.1056/NEJM198110293051808

150. Newcomb RW, Nelson H. Dermographia mediated by immunoglobulin E. Am J Med (1973) 54(2):174-80. doi:10.1016/0002-9343(73)90221-0

151. Morgado-Carrasco D, Fusta-Novell X, Podlipnik S, Combalia A, Aguilera P. Clinical and photobiological response in eight patients with solar urticaria under treatment with omalizumab, and review of the literature. Photodermatol Photoimmunol Photomed (2017). doi:10.1111/phpp.12370

152. Rodriguez-Jimenez P, Chicharro P, Perez-Plaza A, de Argila D. Response to omalizumab in solar urticaria: report of 3 cases. Actas Dermosifiliogr (2017) 108(8):e53-5. doi:10.1016/j.ad.2016.08.011

153. Koumaki D, Seaton ED. Successful treatment of refractory cholinergic urticaria with omalizumab. Int J Dermatol (2018) 57(1):114. doi:10.1111/ ijd. 13808

154. Somers EC, Marder W, Cagnoli P, Lewis EE, DeGuire P, Gordon C, et al. Population-based incidence and prevalence of systemic lupus erythematosus: the michigan lupus epidemiology and surveillance program. Arthritis Rheumatol (2014) 66(2):369-78. doi:10.1002/art.38238

155. Dema B, Charles N, Pellefigues C, Ricks TK, Suzuki R, Jiang C, et al. Immunoglobulin $\mathrm{E}$ plays an immunoregulatory role in lupus. J Exp Med (2014) 211(11):2159-68. doi:10.1084/jem.20140066

156. Yan S, Chen W, Wen S, Zhu W, Guo A, Chen X, et al. Influence of component 5a receptor 1 (C5AR1) - 1330T/G polymorphism on nonsedating H1-antihistamines therapy in Chinese patients with chronic spontaneous urticaria. J Dermatol Sci (2014) 76(3):240-5. doi:10.1016/j.jdermsci.2014. 09.012

157. Yang EM, Kim SH, Kim NH, Park HS. The genetic association of the FPRL1 promoter polymorphism with chronic urticaria in a Korean population. Ann Allergy Asthma Immunol (2010) 105(1):96-7. doi:10.1016/j.anai.2010.05.003

158. Rasool R, Shera IA, Nissar S, Yousuf Q, Shah ZA. IgE FcvarepsilonR1beta polymorphism and risk of developing chronic spontaneous urticaria: a study in an ethnic Kashmiri population. Allergol Immunopathol (Madr) (2015) 43(3):243-8. doi:10.1016/j.aller.2014.04.001

159. Hosseini Farahabadi S, Tavakkol-Afshari J, Ganjali R, Rafatpanah H, Ghaffari J, Farid-Hosseini R. Association between the polymorphism of TGF-betal gene promoter $(-509 \mathrm{C}>\mathrm{T})$ and idiopathic chronic urticaria. Iran J Allergy Asthma Immunol (2006) 5(3):109-13.

160. Park HJ, Ye YM, Hur GY, Kim SH, Park HS. Association between a TGFbeta1 promoter polymorphism and the phenotype of aspirin-intolerant chronic urticaria in a Korean population. JClin Pharm Ther (2008) 33(6):691-7. doi:10.1111/j.1365-2710.2008.00957.x

161. Pan KY, Walls RS, Rajasekariah P, Sherritt M, Warlow RS. Polymorphism of IgE gene in chronic urticaria. Immunol Cell Biol (1996) 74(1):90-5. doi:10.1038/icb.1996.12

162. Palikhe NS, Kim SH, Choi GS, Ye YM, Park HS. No evidence of association between interleukin-13 gene polymorphism in aspirin intolerant chronic urticaria. Allergy Asthma Immunol Res (2009) 1(1):36-40. doi:10.4168/ aair.2009.1.1.36

163. Kim SH, Kang YM, Kim SH, Cho BY, Ye YM, Hur GY, et al. Histamine $\mathrm{N}$-methyltransferase $939 \mathrm{~A}>\mathrm{G}$ polymorphism affects mRNA stability in patients with acetylsalicylic acid-intolerant chronic urticaria. Allergy (2009) 64(2):213-21. doi:10.1111/j.1398-9995.2008.01795.x

164. Brzoza Z, Grzeszczak W, Trautsolt W, Moczulski D. Protein tyrosine phosphatase-22 (PTPN-22) polymorphism in the pathogenesis of chronic urticaria. Allergy (2011) 66(10):1392-3. doi:10.1111/j.1398-9995.2011.02651.x

165. Brzoza Z, Grzeszczak W, Rogala B, Trautsolt W, Moczulski D. PTPN22 polymorphism presumably plays a role in the genetic background of chronic spontaneous autoreactive urticaria. Dermatology (2012) 224(4):340-5. doi:10.1159/000339332
166. Brzoza Z, Grzeszczak W, Rogala B, Trautsolt W, Moczulski D. CTLA-4 polymorphism in the pathogenesis of chronic spontaneous autoreactive urticaria. Allergol Immunopathol (Madr) (2014) 42(3):241-4. doi:10.1016/j. aller.2013.01.008

167. Akcali C, Ozkur M, Erbagci Z, Benlier N, Aynacioglu AS. Association of insertion/deletion polymorphism of the angiotensin-converting enzyme gene with angio-oedema accompanying chronic urticaria but not chronic urticaria without angio-oedema or the autologous serum skin test response. J Eur Acad Dermatol Venereol (2008) 22(1):83-6. doi:10.1111/j.1468-3083.2007. 02353.x

168. Bottini N, Borgiani P, Otsu A, Saccucci P, Stefanini L, Greco E, et al. IL-4 receptor alpha chain genetic polymorphism and total IgE levels in the English population: two-locus haplotypes are more informative than individual SNPs. Clin Genet (2002) 61(4):288-92. doi:10.1034/j.1399-0004.2002.610408.x

169. Shin HD, Park BL, Kim LH, Kim JS, Kim JW. Interleukin-10 haplotype associated with total serum IgE in atopic dermatitis patients. Allergy (2005) 60(9):1146-51. doi:10.1111/j.1398-9995.2005.00839.x

170. Takahashi N, Akahoshi M, Matsuda A, Ebe K, Inomata N, Obara K, et al. Association of the IL12RB1 promoter polymorphisms with increased risk of atopic dermatitis and other allergic phenotypes. Hum Mol Genet (2005) 14(21):3149-59. doi:10.1093/hmg/ddi347

171. Munthe-Kaas MC, Carlsen KH, Helms PJ, Gerritsen J, Whyte M, Feijen $\mathrm{M}$, et al. CTLA-4 polymorphisms in allergy and asthma and the TH1/ TH2 paradigm. J Allergy Clin Immunol (2004) 114(2):280-7. doi:10.1016/j. jaci.2004.03.050

172. Pykalainen M, Kinos R, Valkonen S, Rydman P, Kilpelainen M, Laitinen LA, et al. Association analysis of common variants of STAT6, GATA3, and STAT4 to asthma and high serum IgE phenotypes. J Allergy Clin Immunol (2005) 115(1):80-7. doi:10.1016/j.jaci.2004.10.006

173. Weidinger S, Gieger C, Rodriguez E, Baurecht H, Mempel M, Klopp N, et al. Genome-wide scan on total serum IgE levels identifies FCER1A as novel susceptibility locus. PLoS Genet (2008) 4(8):e1000166. doi:10.1371/journal. pgen. 1000166

174. Hecker M, Bohnert A, Konig IR, Bein G, Hackstein H. Novel genetic variation of human interleukin-21 receptor is associated with elevated IgE levels in females. Genes Immun (2003) 4(3):228-33. doi:10.1038/sj.gene.6363954

175. Pene J, Guglielmi L, Gauchat JF, Harrer N, Woisetschlager M, Boulay V, et al. IFN-gamma-mediated inhibition of human IgE synthesis by IL-21 is associated with a polymorphism in the IL-21R gene. J Immunol (2006) 177(8):5006-13. doi:10.4049/jimmunol.177.8.5006

176. Ozaki K, Spolski R, Feng CG, Qi CF, Cheng J, Sher A, et al. A critical role for IL-21 in regulating immunoglobulin production. Science (2002) 298(5598):1630-4. doi:10.1126/science. 1077002

177. Kotlarz D, Zietara N, Uzel G, Weidemann T, Braun CJ, Diestelhorst J, et al. Loss-of-function mutations in the IL-21 receptor gene cause a primary immunodeficiency syndrome. J Exp Med (2013) 210(3):433-43. doi:10.1084/ jem.20111229

178. Hysi P, Kabesch M, Moffatt MF, Schedel M, Carr D, Zhang Y, et al. NOD1 variation, immunoglobulin E and asthma. Hum Mol Genet (2005) 14(7):935-41. doi: $10.1093 / \mathrm{hmg} / \mathrm{ddi} 087$

179. Chalubinski M, Grzegorczyk J, Grzelak A, Jarzebska M, Kowalski ML. The beta2-adrenoreceptor gene promoter polymorphisms may modulate beta2-agonist- and glucocorticoid-induced IgE synthesis. Allergol Immunopathol (Madr) (2014) 42(6):586-93. doi:10.1016/j.aller.2013. 07.002

180. Pate MB, Smith JK, Chi DS, Krishnaswamy G. Regulation and dysregulation of immunoglobulin E: a molecular and clinical perspective. Clin Mol Allergy (2010) 8:3. doi:10.1186/1476-7961-8-3

181. Kabesch M, Tzotcheva I, Carr D, Hofler C, Weiland SK, Fritzsch C, et al. A complete screening of the IL4 gene: novel polymorphisms and their association with asthma and IgE in childhood. J Allergy Clin Immunol (2003) 112(5):893-8. doi:10.1016/j.jaci.2003.08.033

182. Maurer D, Fiebiger E, Reininger B, Ebner C, Petzelbauer P, Shi GP, et al. Fc epsilon receptor I on dendritic cells delivers IgE-bound multivalent antigens into a cathepsin S-dependent pathway of MHC class II presentation. J Immunol (1998) 161(6):2731-9.

183. Getahun A, Heyman B. IgG- and IgE-mediated antigen presentation on MHC class II. Immunol Lett (2004) 92(1-2):33-8. doi:10.1016/j.imlet.2003.09.015 
184. Alvarez-Errico D, Lessmann E, Rivera J. Adapters in the organization of mast cell signaling. Immunol Rev (2009) 232(1):195-217. doi:10.1111/j.1600-065X.2009.00834.X

185. Campbell AM, Vachier I, Chanez P, Vignola AM, Lebel B, Kochan J, et al. Expression of the high-affinity receptor for IgE on bronchial epithelial cells of asthmatics. Am J Respir Cell Mol Biol (1998) 19(1):92-7. doi:10.1165/ ajrcmb.19.1.2648

186. Redhu NS, Saleh A, Lee HC, Halayko AJ, Ziegler SF, Gounni AS. IgE induces transcriptional regulation of thymic stromal lymphopoietin in human airway smooth muscle cells. J Allergy Clin Immunol (2011) 128(4):892-6.e2. doi:10.1016/j.jaci.2011.06.045

187. Shibaki A. Fc epsilon RI on dendritic cells: a receptor, which links IgE mediated allergic reaction and $\mathrm{T}$ cell mediated cellular response. J Dermatol Sci (1998) 20(1):29-38. doi:10.1016/S0923-1811(99)00003-1

188. Karagiannis SN, Bracher MG, Beavil RL, Beavil AJ, Hunt J, McCloskey N, et al. Role of IgE receptors in IgE antibody-dependent cytotoxicity and phagocytosis of ovarian tumor cells by human monocytic cells. Cancer Immunol Immunother (2008) 57(2):247-63. doi:10.1007/s00262-007-0371-7

189. Shin JS, Greer AM. The role of FcepsilonRI expressed in dendritic cells and monocytes. Cell Mol Life Sci (2015) 72(12):2349-60. doi:10.1007/ s00018-015-1870-x

190. Gounni AS, Lamkhioued B, Ochiai K, Tanaka Y, Delaporte E, Capron A, et al. High-affinity IgE receptor on eosinophils is involved in defence against parasites. Nature (1994) 367(6459):183-6. doi:10.1038/367183a0

191. Alphonse MP, Saffar AS, Shan L, HayGlass KT, Simons FE, Gounni AS. Regulation of the high affinity IgE receptor (Fc epsilonRI) in human neutrophils: role of seasonal allergen exposure and Th-2 cytokines. PLoS One (2008) 3(4):e1921. doi:10.1371/journal.pone.0001921

192. Joseph M, Gounni AS, Kusnierz JP, Vorng H, Sarfati M, Kinet JP, et al. Expression and functions of the high-affinity IgE receptor on human platelets and megakaryocyte precursors. Eur JImmunol (1997) 27(9):2212-8. doi:10.1002/eji.1830270914

193. Hasegawa S, Pawankar R, Suzuki K, Nakahata T, Furukawa S, Okumura K, et al. Functional expression of the high affinity receptor for IgE (FcepsilonRI) in human platelets and its' intracellular expression in human megakaryocytes. Blood (1999) 93(8):2543-51.

194. Charles N, Hardwick D, Daugas E, Illei GG, Rivera J. Basophils and the T helper 2 environment can promote the development of lupus nephritis. Nat Med (2010) 16(6):701-7. doi:10.1038/nm.2159

195. Reich K, Heine A, Hugo S, Blaschke V, Middel P, Kaser A, et al. Engagement of the Fc epsilon RI stimulates the production of IL-16 in langerhans cell-like dendritic cells. J Immunol (2001) 167(11):6321-9. doi:10.4049/ jimmunol.167.11.6321

196. Galli SJ, Tsai M. IgE and mast cells in allergic disease. Nat Med (2012) 18(5):693-704. doi:10.1038/nm.2755

197. MacGlashan DW Jr, Bochner BS, Adelman DC, Jardieu PM, Togias A, McKenzie-White J, et al. Down-regulation of Fc(epsilon)RI expression on human basophils during in vivo treatment of atopic patients with anti-IgE antibody. J Immunol (1997) 158(3):1438-45.

198. Prussin C, Griffith DT, Boesel KM, Lin H, Foster B, Casale TB. Omalizumab treatment downregulates dendritic cell FcepsilonRI expression. J Allergy Clin Immunol (2003) 112(6):1147-54. doi:10.1016/j.jaci.2003.10.003

199. Metz M, Staubach P, Bauer A, Brehler R, Gericke J, Kangas M, et al. Clinical efficacy of omalizumab in chronic spontaneous urticaria is associated with a reduction of FceRI-positive cells in the skin. Theranostics (2017) 7(5):1266-76. doi:10.7150/thno.18304

200. Kitaura J, Kinoshita T, Matsumoto M, Chung S, Kawakami Y, Leitges M, et al. IgE- and IgE+Ag-mediated mast cell migration in an autocrine/paracrine fashion. Blood (2005) 105(8):3222-9. doi:10.1182/blood-2004-11-4205

201. Kitaura J, Song J, Tsai M, Asai K, Maeda-Yamamoto M, Mocsai A, et al. Evidence that IgE molecules mediate a spectrum of effects on mast cell survival and activation via aggregation of the FcepsilonRI. Proc Natl Acad Sci U S A (2003) 100(22):12911-6. doi:10.1073/pnas.1735525100

202. Kashiwakura J, Okayama Y, Furue M, Kabashima K, Shimada S, Ra C, et al. Most highly cytokinergic IgEs have polyreactivity to autoantigens. Allergy Asthma Immunol Res (2012) 4(6):332-40. doi:10.4168/aair.2012.4.6.332

203. Bax HJ, Bowen H, Dodev TS, Sutton BJ, Gould HJ. Mechanism of the antigen-independent cytokinergic SPE-7 IgE activation of human mast cells in vitro. Sci Rep (2015) 5:9538. doi:10.1038/srep09538
204. Greer AM, Wu N, Putnam AL, Woodruff PG, Wolters P, Kinet JP, et al. Serum IgE clearance is facilitated by human FcepsilonRI internalization. JClin Invest (2014) 124(3):1187-98. doi:10.1172/JCI68964

205. Perrigoue JG, Saenz SA, Siracusa MC, Allenspach EJ, Taylor BC, Giacomin $\mathrm{PR}$, et al. MHC class II-dependent basophil-CD4+ T cell interactions promote $\mathrm{T}(\mathrm{H}) 2$ cytokine-dependent immunity. Nat Immunol (2009) 10(7):697-705. doi:10.1038/ni. 1740

206. Yoshimoto T, Yasuda K, Tanaka H, Nakahira M, Imai Y, Fujimori Y, et al. Basophils contribute to $\mathrm{T}(\mathrm{H}) 2$-IgE responses in vivo via IL-4 production and presentation of peptide-MHC class II complexes to CD4+ T cells. Nat Immunol (2009) 10(7):706-12. doi:10.1038/ni.1737

207. Platzer B, Stout M, Fiebiger E. Functions of dendritic-cell-bound IgE in allergy. Mol Immunol (2015) 68(2 Pt A):116-9. doi:10.1016/j.molimm.2015.05.016

208. Bayry J. Lupus pathogenesis: role of IgE autoantibodies. Cell Res (2016) 26(3):271-2. doi:10.1038/cr.2016.12

209. Le T, Tversky J, Chichester KL, Bieneman AP, Huang SK, Wood RA, et al. Interferons modulate Fc epsilon RI-dependent production of autoregulatory IL-10 by circulating human monocytoid dendritic cells. J Allergy Clin Immunol (2009) 123(1):217-23. doi:10.1016/j.jaci.2008.09.013

210. Larson D, Hubner MP, Torrero MN, Morris CP, Brankin A, Swierczewski $\mathrm{BE}$, et al. Chronic helminth infection reduces basophil responsiveness in an IL-10-dependent manner. J Immunol (2012) 188(9):4188-99. doi:10.4049/ jimmunol.1101859

211. Pyle DM, Yang VS, Gruchalla RS, Farrar JD, Gill MA. IgE cross-linking critically impairs human monocyte function by blocking phagocytosis. J Allergy Clin Immunol (2013) 131(2):491-500.e1-5. doi:10.1016/j.jaci.2012.11.037

212. Mellor AL, Munn DH. IDO expression by dendritic cells: tolerance and tryptophan catabolism. Nat Rev Immunol (2004) 4(10):762-74. doi:10.1038/ nri1457

213. Dehlink E, Platzer B, Baker AH, Larosa J, Pardo M, Dwyer P, et al. A soluble form of the high affinity IgE receptor, Fc-epsilon-RI, circulates in human serum. PLoS One (2011) 6(4):e19098. doi:10.1371/journal.pone.0019098

214. Platzer B, Ruiter F, van der Mee J, Fiebiger E. Soluble IgE receptors - elements of the IgE network. Immunol Lett (2011) 141(1):36-44. doi:10.1016/j. imlet.2011.08.004

215. Gould HJ, Sutton BJ. IgE in allergy and asthma today. Nat Rev Immunol (2008) 8(3):205-17. doi:10.1038/nri2273

216. Vercelli D, Helm B, Marsh P, Padlan E, Geha RS, Gould H. The B-cell binding site on human immunoglobulin E. Nature (1989) 338(6217):649-51. doi:10.1038/338649a0

217. Weskamp G, Ford JW, Sturgill J, Martin S, Docherty AJ, Swendeman S, et al. ADAM10 is a principal 'sheddase' of the low-affinity immunoglobulin E receptor CD23. Nat Immunol (2006) 7(12):1293-8. doi:10.1038/ni1399

218. Bansal A, Roberts T, Hay EM, Kay R, Pumphrey RS, Wilson PB. Soluble CD23 levels are elevated in the serum of patients with primary Sjogren's syndrome and systemic lupus erythematosus. Clin Exp Immunol (1992) 89(3):452-5. doi:10.1111/j.1365-2249.1992.tb06979.x

219. Acharya M, Borland G, Edkins AL, Maclellan LM, Matheson J, Ozanne BW, et al. CD23/FcepsilonRII: molecular multi-tasking. Clin Exp Immunol (2010) 162(1):12-23. doi:10.1111/j.1365-2249.2010.04210.x

220. Mudde GC, Bheekha R, Bruijnzeel-Koomen CA. Consequences of IgE/ CD23-mediated antigen presentation in allergy. Immunol Today (1995) 16(8):380-3. doi:10.1016/0167-5699(95)80005-0

221. Cornaby C, Gibbons L, Mayhew V, Sloan CS, Welling A, Poole BD. B cell epitope spreading: mechanisms and contribution to autoimmune diseases. Immunol Lett (2015) 163(1):56-68. doi:10.1016/j.imlet.2014.11.001

222. Jensen-Jarolim E, Singer J. Why could passive Immunoglobulin E antibody therapy be safe in clinical oncology? Clin Exp Allergy (2011) 41(10):1337-40. doi:10.1111/j.1365-2222.2011.03764.x

223. Liu FT, Rabinovich GA. Galectins: regulators of acute and chronic inflammation. Ann N Y Acad Sci (2010) 1183:158-82. doi:10.1111/j.1749-6632.2009. 05131.x

224. Robertson MW, Albrandt K, Keller D, Liu FT. Human IgE-binding protein: a soluble lectin exhibiting a highly conserved interspecies sequence and differential recognition of IgE glycoforms. Biochemistry (1990) 29(35):8093-100. doi:10.1021/bi00487a015

225. de Oliveira FL, Gatto M, Bassi N, Luisetto R, Ghirardello A, Punzi L, et al. Galectin-3 in autoimmunity and autoimmune diseases. Exp Biol Med (Maywood) (2015) 240(8):1019-28. doi:10.1177/1535370215593826 
226. Sanz ML, Prieto I, Garcia BE, Oehling A. Diagnostic reliability considerations of specific IgE determination. J Investig Allergol Clin Immunol (1996) 6(3):152-61.

227. Drinkwater N, Cossins BP, Keeble AH, Wright M, Cain K, Hailu H, et al. Human immunoglobulin E flexes between acutely bent and extended conformations. Nat Struct Mol Biol (2014) 21(4):397-404. doi:10.1038/nsmb. 2795

228. Maurer D, Fiebiger E, Reininger B, Wolff-Winiski B, Jouvin MH, Kilgus O, et al. Expression of functional high affinity immunoglobulin E receptors (Fc epsilon RI) on monocytes of atopic individuals. JExp Med (1994) 179(2):745-50. doi:10.1084/jem.179.2.745

229. Yamaguchi M, Sayama K, Yano K, Lantz CS, Noben-Trauth N, Ra C, et al. IgE enhances $\mathrm{Fc}$ epsilon receptor I expression and IgE-dependent release of histamine and lipid mediators from human umbilical cord blood-derived mast cells: synergistic effect of IL-4 and IgE on human mast cell Fc epsilon receptor I expression and mediator release. J Immunol (1999) 162(9):5455-65.

230. Oda M, Kozono H, Morii H, Azuma T. Evidence of allosteric conformational changes in the antibody constant region upon antigen binding. Int Immunol (2003) 15(3):417-26. doi:10.1093/intimm/dxg036

231. Kochuyt AM. Sensitivity and specificity of food specific IgE and IgG determinations for the diagnosis of food allergy. Acta Gastroenterol Belg (2006) 69(1):43-8.

232. Zimina EP, Fritsch A, Schermer B, Bakulina AY, Bashkurov M, Benzing T, et al. Extracellular phosphorylation of collagen XVII by ecto-casein kinase 2 inhibits ectodomain shedding. J Biol Chem (2007) 282(31):22737-46. doi:10.1074/jbc.M701937200

233. Panneerselvam J, Shanker M, Jin J, Branch CD, Muralidharan R, Zhao YD, et al. Phosphorylation of interleukin (IL)-24 is required for mediating its anti-cancer activity. Oncotarget (2015) 6(18):16271-86. doi:10.18632/ oncotarget.3977

234. Zimina EP, Hofmann SC, Fritsch A, Kern JS, Sitaru C, Bruckner-Tuderman L. Bullous pemphigoid autoantibodies preferentially recognize phosphoepitopes in collagen XVII. J Invest Dermatol (2008) 128(11):2736-9. doi:10.1038/ jid.2008.132

235. Schreiber A, Rolle S, Peripelittchenko L, Rademann J, Schneider W, Luft FC, et al. Phosphoinositol 3-kinase-gamma mediates antineutrophil cytoplasmic autoantibody-induced glomerulonephritis. Kidney Int (2010) 77(2):118-28. doi:10.1038/ki.2009.420

236. Sircar G, Jana K, Dasgupta A, Saha S, Gupta Bhattacharya S. Epitope mapping of Rhi o 1 and generation of a hypoallergenic variant: a candidate molecule for fungal allergy vaccines. J Biol Chem (2016) 291(34):18016-29. doi:10.1074/ jbc.M116.732032

237. Yeh CC, Tai HY, Chou H, Wu KG, Shen HD. Vacuolar serine protease is a major allergen of Fusarium proliferatum and an IgE-cross reactive pan-fungal allergen. Allergy Asthma Immunol Res (2016) 8(5):438-44. doi:10.4168/ aair.2016.8.5.438

238. Donovan GR, Baldo BA. Crossreactivity of IgE antibodies from sera of subjects allergic to both ryegrass pollen and wheat endosperm proteins: evidence for common allergenic determinants. Clin Exp Allergy (1990) 20(5):501-9. doi:10.1111/j.1365-2222.1990.tb03142.x

239. Jappe U, Raulf-Heimsoth M, Hoffmann M, Burow G, Hubsch-Muller C, Enk A. In vitro hymenoptera venom allergy diagnosis: improved by screening for cross-reactive carbohydrate determinants and reciprocal inhibition. Allergy (2006) 61(10):1220-9. doi:10.1111/j.1398-9995.2006.01232.x

240. Mahler V, Gutgesell C, Valenta R, Fuchs T. Natural rubber latex and hymenoptera venoms share ImmunoglobinE-epitopes accounting for cross-reactive carbohydrate determinants. Clin Exp Allergy (2006) 36(11):1446-56. doi:10.1111/j.1365-2222.2006.02587.x

241. Carballada FJ, Gonzalez-Quintela A, Nunez-Orjales R, Vizcaino L, Boquete M. Double (honeybee and wasp) immunoglobulin E reactivity in patients allergic to hymenoptera venom: the role of cross-reactive carbohydrates and alcohol consumption. J Investig Allergol Clin Immunol (2010) 20(6):484-9.

242. Pham NH, Baldo BA. Allergenic relationship between taxonomically diverse pollens. Clin Exp Allergy (1995) 25(7):599-606. doi:10.1111/j.13652222.1995.tb01107.x
243. Twardosz A, Hayek B, Seiberler S, Vangelista L, Elfman L, Gronlund H, et al. Molecular characterization, expression in Escherichia coli, and epitope analysis of a two EF-hand calcium-binding birch pollen allergen, Bet v 4. Biochem Biophys Res Commun (1997) 239(1):197-204. doi:10.1006/bbrc.1997. 6860

244. Oberhuber C, Ma Y, Wopfner N, Gadermaier G, Dedic A, Niggemann B, et al. Prevalence of IgE-binding to Art v 1, Art v 4 and Amb a 1 in mugwort-allergic patients. Int Arch Allergy Immunol (2008) 145(2):94-101. doi:10.1159/000108134

245. Tinghino R, Twardosz A, Barletta B, Puggioni EM, Iacovacci P, Butteroni C, et al. Molecular, structural, and immunologic relationships between different families of recombinant calcium-binding pollen allergens. JAllergy Clin Immunol (2002) 109(2):314-20. doi:10.1067/mai.2002.121528

246. Mares-Mejia I, Martinez-Caballero S, Garay-Canales C, Cano-Sanchez P, Torres-Larios A, Lara-Gonzalez S, et al. Structural insights into the IgE mediated responses induced by the allergens Hev b 8 and Zea $\mathrm{m} 12$ in their dimeric forms. Sci Rep (2016) 6:32552. doi:10.1038/srep32552

247. Chelminska M, Specjalski K, Rozylo A, Kolakowska A, Jassem E. Differentiating of cross-reactions in patients with latex allergy with the use of ISAC test. Postepy Dermatol Alergol (2016) 33(2):120-7. doi:10.5114/ ada.2016.59154

248. Aalberse RC, Crameri R. IgE-binding epitopes: a reappraisal. Allergy (2011) 66(10):1261-74. doi:10.1111/j.1398-9995.2011.02656.x

249. Fahlbusch B, Rudeschko O, Schumann C, Steurich F, Henzgen M, Schlenvoigt G, et al. Further characterization of IgE-binding antigens in kiwi, with particular emphasis on glycoprotein allergens. J Investig Allergol Clin Immunol (1998) 8(6):325-32.

250. Son DY, Scheurer S, Hoffmann A, Haustein D, Vieths S. Pollen-related food allergy: cloning and immunological analysis of isoforms and mutants of Mal $\mathrm{d} 1$, the major apple allergen, and Bet v 1, the major birch pollen allergen. Eur J Nutr (1999) 38(4):201-15. doi:10.1007/s003940050063

251. Gavrovic-Jankulovic M, Cirkovic T, Burazer L, Vuckovic O, Jankov RM. IgE cross-reactivity between meadow fescue pollen and kiwi fruit in patients' sera with sensitivity to both extracts. J Investig Allergol Clin Immunol (2002) 12(4):279-86.

252. Cudowska B, Kaczmarski M, Restani P. Immunoblotting in the diagnosis of cross-reactivity in children allergic to birch. Rocz Akad Med Bialymst (2005) 50:268-73.

253. Iraneta SG, Seoane MA, Laucella SA, Apicella C, Alonso A, Duschak VG. Antigenicity and immunocrossreactivity of orange tree pollen and orange fruit allergenic extracts. Int Arch Allergy Immunol (2005) 137(4):265-72. doi:10.1159/000086419

254. Madhurantakam C, Nilsson OB, Uchtenhagen H, Konradsen J, Saarne T, Hogbom E, et al. Crystal structure of the dog lipocalin allergen Can $\mathrm{f} 2$ : implications for cross-reactivity to the cat allergen Fel d 4. J Mol Biol (2010) 401(1):68-83. doi:10.1016/j.jmb.2010.05.043

255. Apostolovic D, Sanchez-Vidaurre S, Waden K, Curin M, Grundstrom J, Gafvelin G, et al. The cat lipocalin Fel d 7 and its cross-reactivity with the dog lipocalin Can f 1. Allergy (2016) 71(10):1490-5. doi:10.1111/ all.12955

256. Hemmer W, Klug C, Swoboda I. Update on the bird-egg syndrome and genuine poultry meat allergy. Allergo J Int (2016) 25:68-75. doi:10.1007/ s40629-016-0108-2

257. Kuehn A, Codreanu-Morel F, Lehners-Weber C, Doyen V, Gomez-Andre SA, Bienvenu F, et al. Cross-reactivity to fish and chicken meat - a new clinical syndrome. Allergy (2016) 71(12):1772-81. doi:10.1111/all.12968

258. Jeong KY, Son M, Park JH, Park KH, Park HJ, Lee JH, et al. Cross-reactivity between oak and birch pollens in Korean tree pollinosis. J Korean Med Sci (2016) 31(8):1202-7. doi:10.3346/jkms.2016.31.8.1202

259. Doenhoff MJ, El-Faham M, Liddell S, Fuller HR, Stanley RG, Schramm G, et al. Cross-reactivity between Schistosoma mansoni antigens and the latex allergen Hev b 7: putative implication of cross-reactive carbohydrate determinants (CCDs). PLoS One (2016) 11(7):e0159542. doi:10.1371/journal. pone. 0159542

260. Santiago Hda C, Nutman TB. Role in allergic diseases of immunological cross-reactivity between allergens and homologues of parasite proteins. Crit Rev Immunol (2016) 36(1):1-11. doi:10.1615/CritRevImmunol.2016016545 
261. Utsch L, Logiantara A, Wallner M, Hofer H, van Ree R, van Rijt LS. Birch pollen immunotherapy inhibits anaphylaxis to the cross-reactive apple allergen Mal d 1 in mice. Clin Exp Allergy (2016) 46(11):1474-83. doi:10.1111/ cea. 12775

262. Geroldinger-Simic M, Kinaciyan T, Nagl B, Baumgartner-Durchschlag $\mathrm{U}$, Huber H, Ebner C, et al. Oral exposure to Mal d 1 affects the immune response in patients with birch pollen allergy. J Allergy Clin Immunol (2013) 131(1):94-102. doi:10.1016/j.jaci.2012.06.039

263. Matricardi PM, Kleine-Tebbe J, Hoffmann HJ, Valenta R, Hilger C, Hofmaier $\mathrm{S}$, et al. EAACI molecular allergology user's guide. Pediatr Allergy Immunol (2016) 27(Suppl 23):1-250. doi:10.1111/pai.12563
Conflict of Interest Statement: The authors declare that the research was conducted in the absence of any commercial or financial relationships that could be construed as a potential conflict of interest.

Copyright $\odot 2018$ Maurer, Altrichter, Schmetzer, Scheffel, Church and Metz. This is an open-access article distributed under the terms of the Creative Commons Attribution License (CC BY). The use, distribution or reproduction in other forums is permitted, provided the original author(s) and the copyright owner are credited and that the original publication in this journal is cited, in accordance with accepted academic practice. No use, distribution or reproduction is permitted which does not comply with these terms. 